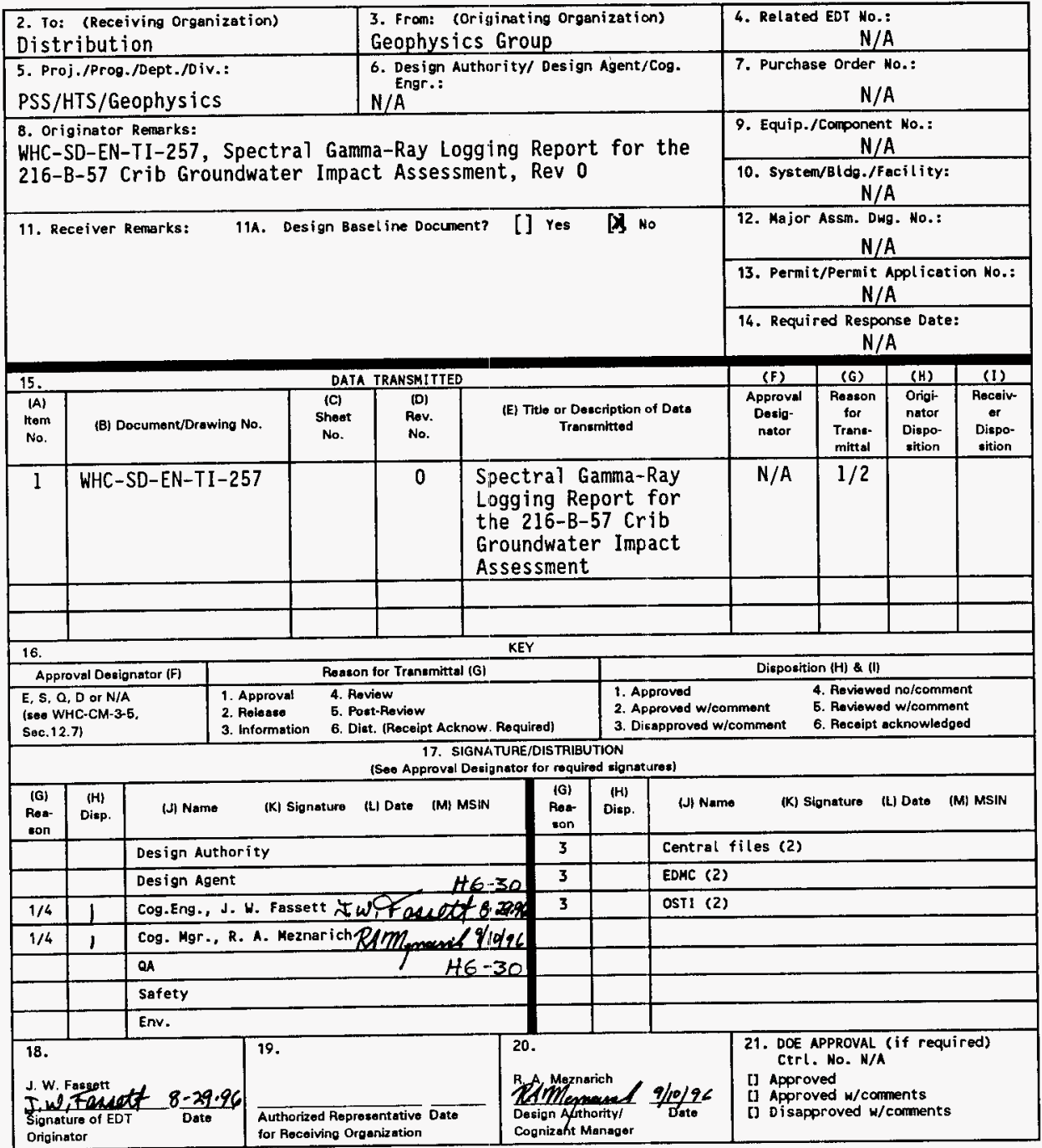

BD-7400-172-2(05/96) GEF097 


\title{
Spectral Gamma-Ray Logging Report for the 216-B-57 Crib Groundwater Impact Assessment
}

\author{
G. J. Szwartz \\ Westinghouse Hanford Company, Richland, WA 99352 \\ U.S. Department of Energy Contract DE-ACO6-87RL10930
EDT/ECN: 610764 UC: 630
Org Code: 8H100 Charge Code: R4V11
B\&R Code: EW3120100 Total Pages: 48

Key Words: Geophysics, gamma-ray, RLS, logging

Abstract: Using the In Situ Characterization Probe to place access holes near the 216-B-57 Crib, the Radionuclide Logging System was used to further characterize the radioelement contamination surrounding the crib. Data collection was not completely successful in that the logging sonde was not able to go the full depth of each of the access holes. However, significant data were gather and analyzed to meet the objective of the effort.

TRADEMARK DISCLAIMER. Reference herein to any specific commercial product, process, or service by trade name, trademark, manufacturer, or otherwise, does not necessarily constitute or imply its. endorsement, recommendation, or favoring by the United states Government or any agency thereof or its contractors or subcontractors.

Printed in the United States of America. To obtain copies of this document, contact: WHC/BCS Document Control Services, P.0. Box 1970, Mailstop H6-08, Richland WA 99352, Phone (509) 372-2420; Fax (509) $376-4989$.
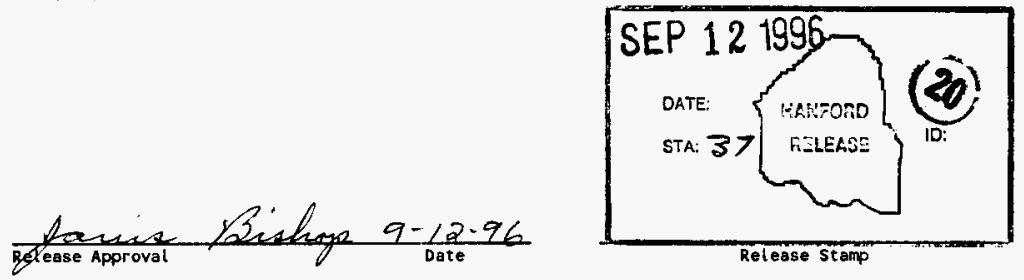

Approved for Public Release 
WHC-SD-EN-TI-257, Rev 0

\section{CONTENTS}

1.0 INTRODUCTION $\ldots \ldots \ldots \ldots \ldots \ldots \ldots \ldots \ldots \ldots \ldots \ldots \ldots \ldots \ldots$

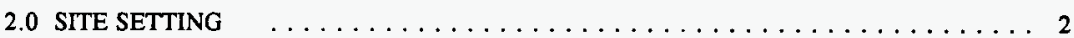

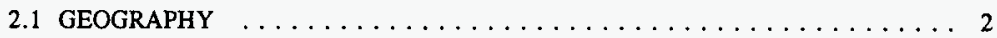

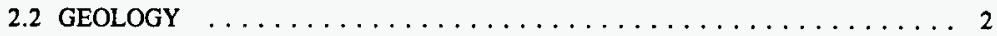

2.3 HISTORY $\ldots \ldots \ldots \ldots \ldots \ldots \ldots \ldots \ldots \ldots \ldots \ldots \ldots \ldots \ldots \ldots \ldots \ldots \ldots \ldots$

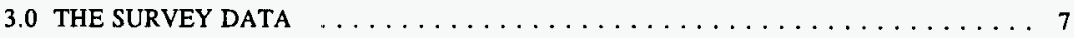

4.0 CONCLUSIONS $\ldots \ldots \ldots \ldots \ldots \ldots \ldots \ldots \ldots \ldots \ldots \ldots \ldots$

5.0 FUTURE CONSIDERATIONS $\ldots \ldots \ldots \ldots \ldots \ldots \ldots \ldots \ldots \ldots \ldots$

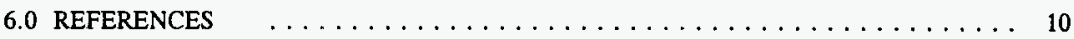

\section{FIGURES}

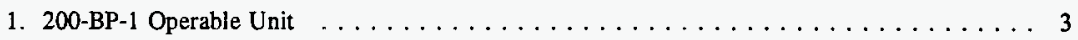

2. Well Locations Characterizing Crib 216-B-57 . . . . . . . . . . . . 4

3. 216-B-57 Crib Cross-Section and Well Sample Intervals $\ldots \ldots \ldots \ldots \ldots$ 
WHC-SD-EN-T1-257, Rev 0

\section{TABLES}

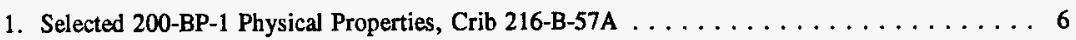

2. Summary of Maximum Radionuclide Depths from RLS Log

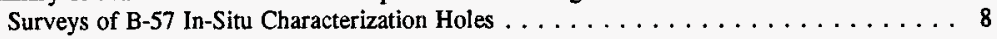

3. Anthropogenic Radionuclide Detection Intervals and Activity Levels $\ldots \ldots \ldots \ldots$

\section{APPENDICES}

A Radionuclide Logging System (RLS) Data for In-situ

Characterization Hole GP-5 . . . . . . . . . . . . . . . A-1

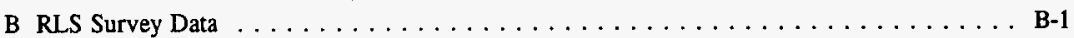

C RLS Data for Other Holes in the Vicinity of Crib $216-\mathrm{B}-57 \ldots \ldots \ldots \ldots \ldots \ldots \ldots$ C-1

D The RLS System, It's Data and Data Analysis Limitations . . . . . . . . D-1 
WHC-SD-EN-TI-257, Rev 0

\section{SPECTRAL GAMMA-RAY LOGGING REPORT FOR THE 216-B-57 CRIB GROUNDWATER IMPACT ASSESSMENT}

\subsection{INTRODUCTION}

Characterization boreholes were drilled through The B-57 Crib in 1991, samples taken and analyzed, and the Radionuclide Logging System (RLS) was used to geophysical log the boreholes to assay the quantities of anthropogenic (man-made) radioisotopes surrounding the boreholes. (The RLS is a high-resolution, high-purity germanium (HPGe), passive, spectral gamma-ray detection system that measures subsurface gamma-ray radiation intensity and its vertical distribution.)

As a continuation to that program and to further assess the extent of the radioactive contamination around the 216-B-57 Crib, four additional subsurface access holes were constructed so that additional radionuclide concentration data could be collected with the RLS and used to again assay the radioisotopes around the access holes, or ports, in the vicinity of the crib to aide in the subsurface characterization of the 216-B-57 Crib. The RLS data will be used to define the maximum horizontal extent of the subsurface contamination. Contamination was detected in only three of the four holes, two at near-surface and one (GP-9) at a depth of $33 \mathrm{ft}$.

These access holes have been designated "In Situ Characterization Probe Subsurface Access Holes: GP-6, GP-7, GP-9 \& GP-9" and were constructed with the "In Situ Characterization Probe", a diesel-powered, pile-driving machine used to drive down to "depth" 4- or 5-inch drill string with a cone mounted on the first string.

The contents of this report are limited to the description of the survey results for each access hole logged. A description and details of the RLS System and how it worked in this project and the limitations to radioelement analysis are contained in Appendix D. It is strongly recommended that readers unfamiliar with this very sophisticated, state-of-the-art logging system refer to this appendix, and they are urged to peruse it for pertinent information to familiarized themselves with its detailed capabilities and limitation.

Details of equipment configuration, calibration, logging procedures, casing and water correction factors, spectral analysis software, and data management have been excluded from this report. The details of these topics are described in the papers cited. 


\subsection{SIIE SETTING}

\subsection{GEOGRAPHY}

The 216-B-57 Crib is one of ten inactive cribs within the 200-BP-1 Operable Unit (Figure 1). The operable unit was also the site of four unplanned releases.

To date there have been at least nine boreholes constructed within $100 \mathrm{ft}$ of the 216-B-57 Crib boundaries, as defined by engineering drawings. Three of these boreholes (299-E33-304, 299-E33305, and 299-E33-306) were drilled through the crib in three locations for sample retrieval and geophysical logging. They have since been plugged and abandoned. Also a groundwater well (299E33-24) is in place just to the west side of the crib, Figure 2.

A total of five In Situ Characterization Probe holes (GP-5, GP-6, GP-7, GP-8, and GP-9) were installed to characterize the horizontal extent of the radioactive contamination. All boreholes and adjacent probe locations can be found in Figure 2.

\subsection{GEOLOGY}

The 200-BP-1 Operable Unit is situated at an average elevation of approximately 192 meters (630 ft) above mean see level on the Cold Creek flood bar (Bretz et.al., 1956). The geologic units of interest found in the vicinity of the 200-BP-1 Operable Unit include from oldest to youngest: (1) the Ringold Formation, (2) the Hanford formation, and (3) the Holocene surficial deposits. B-57 Crib site data were taken in boreholes 299-E33-304, -305, and -306; initially identified as 216-B-57A, 57B, and $-57 \mathrm{C}$. Three holes were split-spoon sampled and geologically logged from drill collar to hole bottom. Well summary sheets can be found in Hoffman, 1992 (WHC-SD-EN-TI-054, Rev. 0). Figure 3 shows where the samples were collected for chemical analysis, as well as soil-gravel-soil interfaces. These samples reveal a porous and dry subsurface.

Selected physical properties of the 216-Ei-57A borehole are presented below in Table 1 . This data is provided to establish the hypothesis that horizontal migration of contamination will be limited due to the high porosity and low saturation of the gravel/sand subsurface. For more information see WHC-SD-EN-TI-054, Rev 0. 


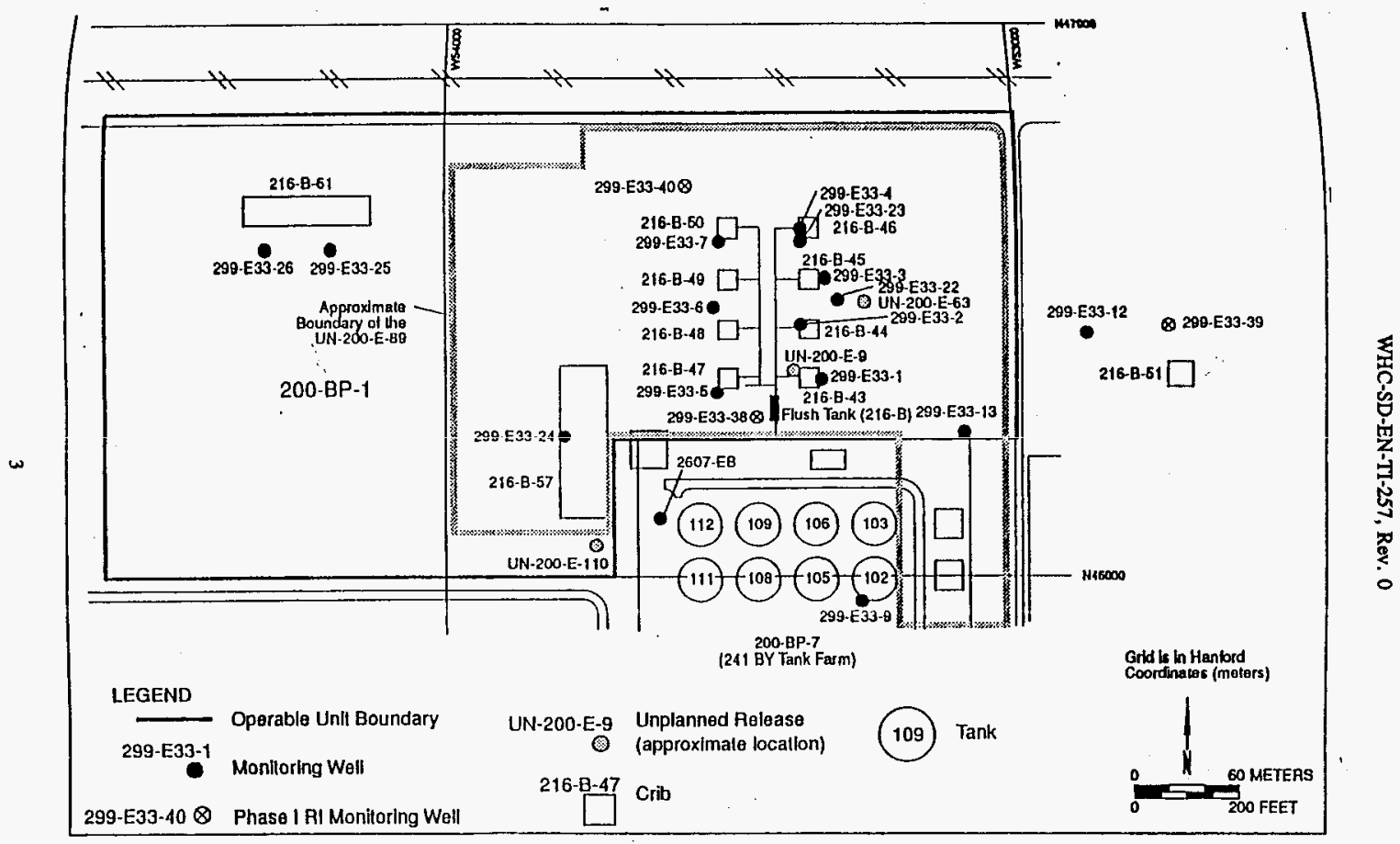

Figure 1: 200 BP-1 Operable Unit 
WHC-SD-EN-TI-257, Rev. 0

Figure 2: Well Locations Characterizing Crib 216-B-57

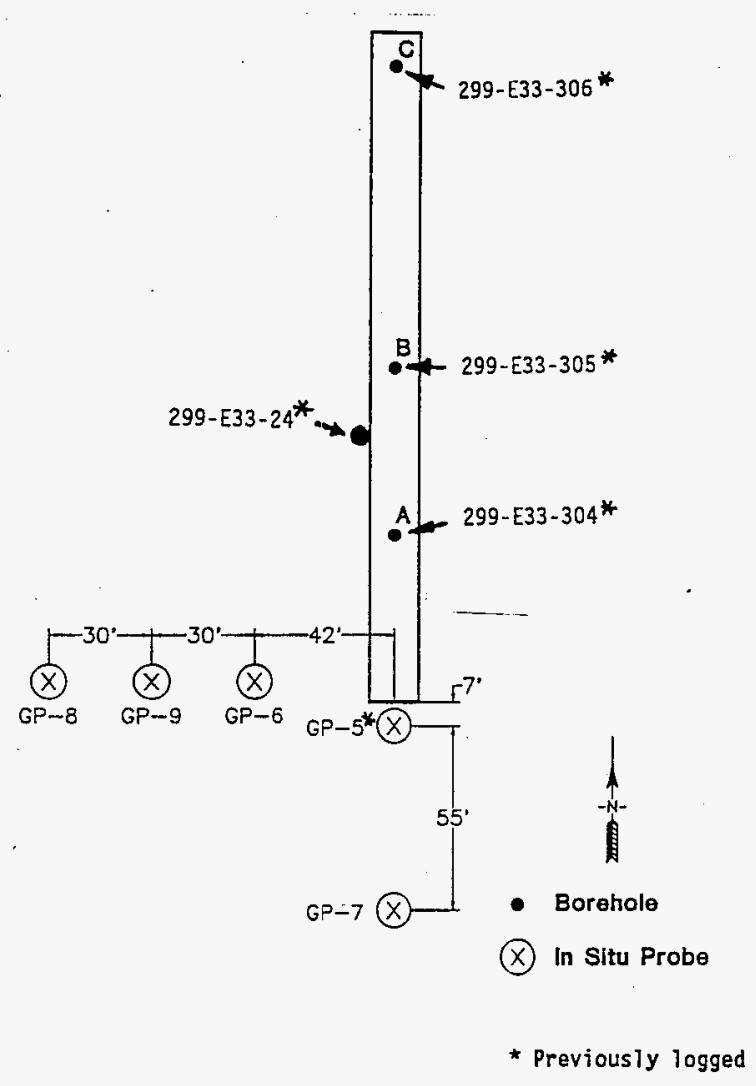




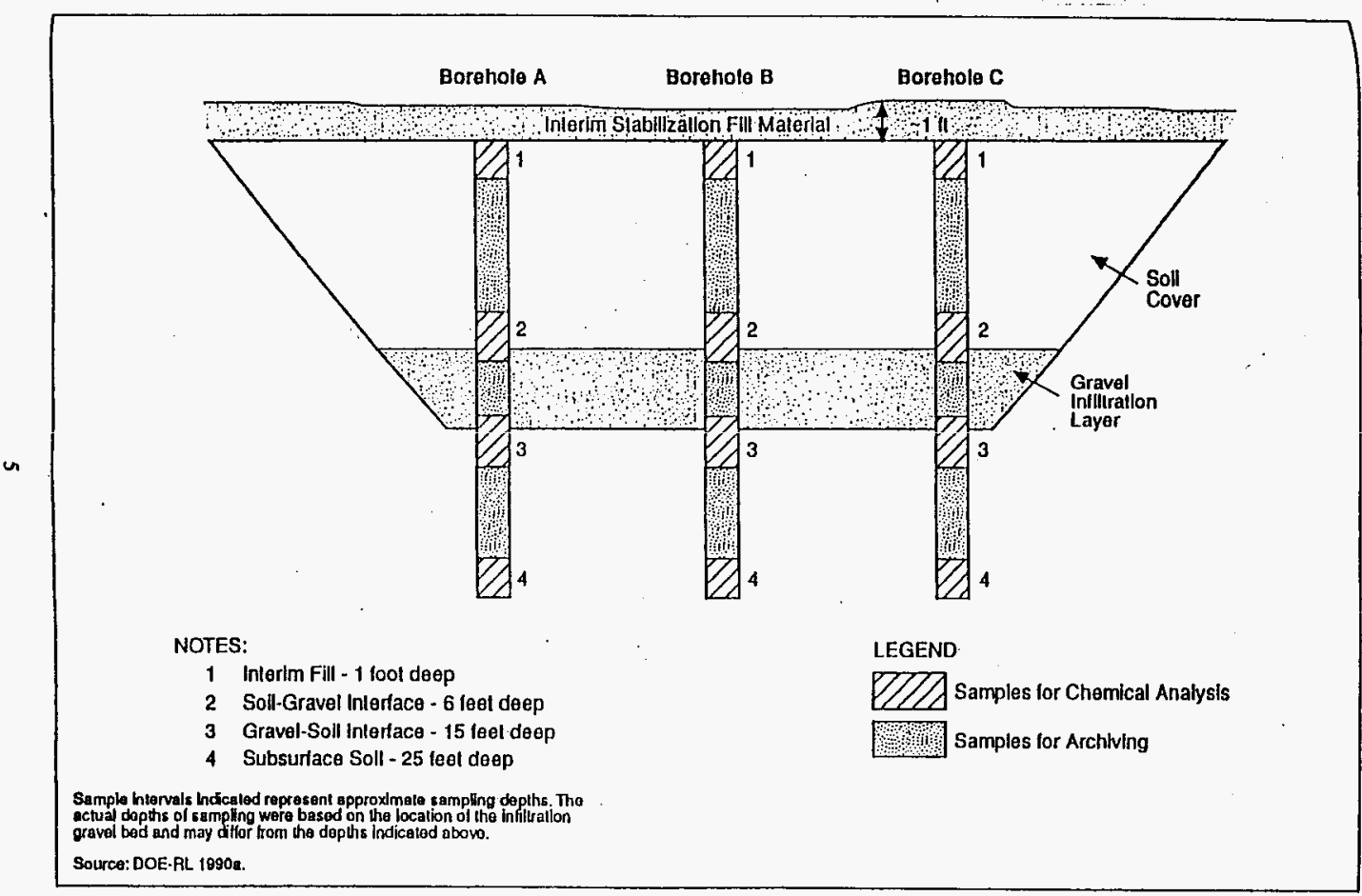

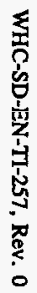

Figure 3: 216-8-57 Crib Cross-Section and Well Sample Intervals 
WHC-SD-EN-TI-257, Rev 0

Table 1. Selected 200-BP-1 Physical Properties

CRIB 216-B-57A

\begin{tabular}{|c|c|c|c|}
\hline $\begin{array}{c}\text { Footage (ft) } \\
\text { Below Surface }\end{array}$ & Moisture (wt\%) & Porosity (\%) & $\begin{array}{c}\text { Specific } \\
\text { Gravity }\end{array}$ \\
\hline 15.0 & 2.60 & 23.89 & 2.74 \\
\hline 26.0 & 3.18 & 25.46 & 2.66 \\
\hline 40.5 & 1.71 & 38.06 & 2.71 \\
\hline 48.0 & 2.22 & 35.79 & 2.68 \\
\hline
\end{tabular}

\subsection{HISTORY}

The 216-B-57 Crib received in-tank solidification (ITS) condensates that were low-level wastes. These ITS waste streams were considered suitable for crib disposal and vadose infiltration in large volumes.

An as-built drawing for crib 216-B-57 (WHC Drawing H-2-78769, Rev. 0) in DOE/RL, 1990 indicates that the crib consists of a $30.5-\mathrm{cm}(12$-in.) corrugated and perforated steel pipe that runs the length of the $61-\mathrm{m}(200-\mathrm{ft})$ long and $4.6-\mathrm{m}(15-\mathrm{ft})$ wide crib. The base of the $3-\mathrm{m}(10-\mathrm{ft})$ deep excavation is level, and the pipe within it dips down from the South to the North. The crib bottom is

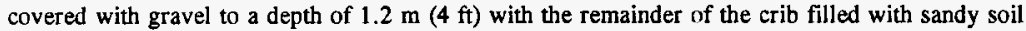
(Figure 3). Side slopes are 1.5:1.

As discussed earlier and identified on Figure 2, RLS logging surveys were previously acquired in boreholes: 299-E33-304 (233 ft total depth (TD)), 299-E33-305 (50 ft TD), 299-E33-306 (50 ft TD), 299-E33-24 (249.7 ft TD), and in the In-Situ Characterization Hole GP-5 (47 ft TD). Holes 299-E33-304, 299-E33-305, and GP-5 showed gamma radiation from a man-made source (cesium-137). Gamma-ray radiation from man-made sources was not detected in borehole 299-E33306. For complete RLS logging results of GP-5 and the four in situ access holes, see Appendices A and B, respectively. The probe locations for GP-6 through GP-9 were selected largely due to the results of these previous surveys. Mostly, the probe locations were chosen to define the extent of the man-made radionuclide contamination and its horizontal migration 


\subsection{THE SURVEY DATA}

The tables in Appendix B entitled "RLS Spectral Gamma-Ray Borehole Survey Log Header" summarize the borehole and survey information. Plots of the total gamma-ray counts per second (Total Gamma) along with the calculated man-made isotope concentrations are presented on the page following the header. The "Total Gamma" is the count rate for all gamma rays detected by the RLS detector, with no discrimination of gamma-ray energy. The Total Gamma is equivalent to the gross gamma-ray log commonly used in the past at Hanford.

The plots of radionuclide-activity response versus depth are shown in Appendix $B$ along with notes and a summary. On the plots of Appendix B, a uniform depth scale of $20 \mathrm{ft}$ per inch, and a radionuclide-concentration scale of $40 \mathrm{pCi} / \mathrm{g}$ per inch are used. The experimental uncertainties in the computed radionuclide activities are not presented on the data plots at this time.

The decay activity for the natural radionuclides, potassium, uranium, and thorium, have been computed through the normal spectral analysis of the data reduction program and are presented, with the Total Gamma, on the page following the plots of the other data.

Long-count, stationary measurements of at least 300 seconds (shown as short bars in the plotted data and best seen in the plots of the potassium, uranium and thorium channels for access holes CP-6 at a depth of $12 \mathrm{ft}$ and CP-9 at a depth of $32 \mathrm{ft}$ ) were recorded at some depth points (stations) in all holes to verify the validity of the data acquired with the 80-seconds-per-half-ft survey. Both the long and 80 -second measurements were acquired at essentially some given common depth. The extended acquisition time did not identify additional radionuclides in any of these wells or in situ characterization holes.

Table 2, below, summarizes the maximum depths that man-made radionuclides were detected and differentiated by spectral analysis. Table 3 summarizes all intervals of man-made radionuclide detection and the maximum activity levels detected. The only man-made, gamma-ray-emitting radionuclide identified was cesium- 137 . 
WHC-SD-EN-TI-257, Rev 0

Table 2. Summary of Maximum Radionuclide Depths from RLS Log Surveys of B-57 In-Situ Characterization Holes.

\begin{tabular}{||l|c|c|c|c||}
\hline $\begin{array}{c}\text { Access Hole } \\
\text { ID }\end{array}$ & $\begin{array}{c}\text { Survey } \\
\text { Date }\end{array}$ & $\begin{array}{c}\text { Borehole } \\
\text { Depth }\end{array}$ & $\begin{array}{c}\text { Survey } \\
\text { Depth }^{2}\end{array}$ & $\begin{array}{c}\text { Cesium-137 } \\
\text { Depth }^{3}\end{array}$ \\
\hline \hline GP-6 & $03 / 05 / 93$ & $48.88^{\prime}$ & $12.5^{\prime}$ & - \\
\hline GP-7 & $03 / 05 / 93$ & $47.5^{\prime}$ & $43.5^{\prime}$ & $2^{\prime}$ \\
\hline GP-8 & $03 / 08 / 93$ & $46.2^{\prime}$ & $18.5^{\prime}$ & $0.5^{\prime}$ \\
\hline GP-9 & $03 / 09 / 93$ & $49.2^{\prime}$ & $46.5^{\prime}$ & $31-33^{\prime}$ \\
\hline
\end{tabular}

'Date survey was completed

${ }^{2}$ Maximum survey depth

${ }^{3}$ Maximum depth where radionuclide was identified

Table 3. Anthropogenic Kadionuclide Detection Intervals, and Activity Levels.

\begin{tabular}{||c|c|c|c|}
\hline $\begin{array}{c}\text { Access Hole } \\
\text { ID }\end{array}$ & $\begin{array}{c}\text { Interval(s) } \\
\text { of Cesium-137 } \\
\text { Detection }\end{array}$ & $\begin{array}{c}\text { Depth of } \\
\text { Maximum Activity } \\
\text { Detected }\end{array}$ & $\begin{array}{c}\text { Maximum Cesium-137 } \\
\text { Detected (pCi/g })^{1}\end{array}$ \\
\hline GP-6 & - & - & - \\
\hline GP-7 & $0-2.0^{\prime}$ & $1.0^{\prime}$ & $4.0 \mathrm{pCi} / \mathrm{g}$ \\
\hline GP-8 & $0-0.5^{\prime}$ & surface & $0.7 \mathrm{pCi} / \mathrm{g}$ \\
\hline GP-9 & $31.0-33.0^{\prime}$ & $32.0^{\prime}$ & $3.0 \mathrm{pCi} / \mathrm{g}$ \\
\hline
\end{tabular}

'Picocuries per gram.

\subsection{CONCLUSIONS}

The minor cesium-137 contamination in hole GP-9 at the depth interval of 31 to $33 \mathrm{ft}$ is most likely a product of horizontal migration from the 216-B-57 Crib. In situ characterization holes GP-6 and GP-8 had too much curvature for the RLS tool to fit down hole to a depth of $30 \mathrm{ft}$. This limitation on survey depth prevented collecting data from these holes to confirm or deny the presence of cesium-137 at the 31- to 33-ft depth below the surface as detected in hole GP-9. (The Westinghouse Borehole Geophysics Group has since thinned the diameter of the tool, to lessen RLS limitations in the future.) 
As seen in Appendix A, the results of data analysis of In Situ Characterization Hole GP-5 show there is abundant cesium-137 gamma-ray energy detected approximately $18 \mathrm{ft}$ down. The proximity of GP-5 to the perforated pipe that feeds the crib supports the reasonableness of the high cesium-137 readings.

The geology of this site is characterized by the presence of "gravelly sand" with moisture less than $4 \%$ by weight and porosity no less than $24 \%$ (Buckmaster 1992). Based on this characterization, it is reasonable to assume that radionuclide travel in a horizontal direction would be limited, if not absent. The high activity of cesium-137 in hole GP-5, and the absence of cesium in GP-7 at, or around, a depth of $18 \mathrm{ft}$, may support the theory of minimal horizontal flow for radioactive contamination. Conversely, the presence of cesium-137 in access hole GP-9 (and the possibility of its presence in GP-6) would suggest minimal horizontal migration, but with a preferred direction.

\subsection{FUTURE CONSIDERATIONS}

The RLS gamma-ray logging probe can be made even thinner than the existing one. This smaller diameter would allow the tool to be used to log wells that have a down-hole radius of curvature too great to allow use of the present tool. Holes GP-6 and GP-8 were two such holes. Reducing the diameter of the RLS tool will be considered.

Spectral analysis of data from groundwater well 299-E33-24 indicates activity of man-made cobalt-60 from approximately 230-244 ft (Appendix C). Well 299-E33-05 is the next closest groundwater well to the $216-\mathrm{B}-57 \mathrm{Crib}$, and it is part of the 216-B-47 Crib characterization. In the plot provided in Appendix C, well 299-E33-05 also shows cobalt-60 activity at a depth of approximately 225 to $233 \mathrm{ft}$. Wells in the area may be examined to attempt to characterize the cobalt -60 level in the groundwater. There are numerous wells in the area of crib 216-B-57 which can be studied comprehensively and simultaneously to determine the spacial relationship between detected man-made radionuclides and the distance from the perforated pipe in the crib. A geostatistical analysis of this spacial relationship may yield estimated concentrations of radionuclide contamination in three dimensions. However, this type of theoretical modelling is inappropriate at this time for the needs of the project and the effort required. 
WHC-SD-IEN-TI-257, Rev 0

\subsection{REFERENCES}

Bretz, J.H., Smith, H.T.U. and Neff, G.E., 1965, Channel Scabland of Washington: New Data and Interpretation, Geological Society of America Bulletin, Vol 67, pp. 957-1049.

Brodeur, J.R., Koizumi, C.J., Ulbricht, W.H. and Price, R.K., 1991, Calibration of a HighResolution Passive Gamma-Ray Logging System for Nuclear Waste Assessment, WHC-SA-1175-FP, Westinghouse Hanford Company, Richland, Washington.

Brodeur, J. R, C. J. Koizumi, R. K. Price, and R. D. Wilson, 1992, Gamma-Ray Logging Results for the 200 Aggregate Area Management Study, WHC-SD-EN-TI-021, Westinghouse Hanford Company, Richland, Washington.

Buckmaster, M.A., 1992, Summary of the Geology of the 200-BP-1 Operable Unit, Rev. 0, WHC-SD-EN-TI-037, Westinghouse Hanford Company, Richland, Washington.

DOE-RL, 1990, Remedial Investigation/Feasibility Study Work Plan for the 200-BP-1 Operable Unit, Hanford Site, Richland, Washington, DOE-RL 88-32, U.S. Department of Energy, Richland Washington, Plate 2-5.

Erdtmann, G., and Soyka, W., 1979, The Gamma Rays of the Radionuclides, Verlag Chemie GmbF, Weinheim, Germany.

Hoffman, K.M., 1992, 200-BP-1 Borehole Summary Report for Tasks 2, 4, and 6, WHC-SD-EN-TI-054, Rev. 0, Westinghouse Hanford Company, Richland, Washington.

Koizumi, C.J., Brodeur, J.R., Ulbricht, W.H. and Price, R.K. 1991, Calibration of the RLS HPGe Spectral Gamma-Ray Logging System, WHC-EP-0464, Westinghouse Hanford Company, Richland, Washington.

Koizumi, C.J., Price, R.K. and Wilson, R.D., 1992, Calibration of the RLS System for 200 Aggregate Area Management Study Screening Measurements, WHC-SD-EN-TRP-001, Westinghouse Hanford Company, Richland, Washington. 
WHC-SD-EN-TI-257, Rev 0

APPENDIX A

RLS Data for In-Situ Characterization Hole GP-5

A-1 
WHC-SD-EN-TI-257, Rev 0

This page intentionally left blank.

A-2 
WHC-SD-EN-TI-257, Rev. 0

\section{Westinghouse Hanford Company \\ RLS Spectral Gamma-Ray Borehole Survey Log Header}

Project: Cone Penetrometer Tech. Dev

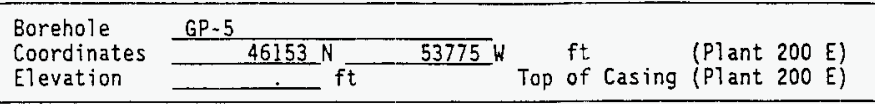

Borehole Environment Information

\begin{tabular}{|c|c|c|c|}
\hline Borehole Fluid Depth none (ft) from Zero (0.0) Depth Reference of Log \\
\hline $\begin{array}{c}\text { Casing Size } \\
\text { I.D. (in) }\end{array}$ & $\begin{array}{c}\text { Casing Thickness } \\
\text { (in) }\end{array}$ & $\begin{array}{c}\text { Top Depth } \\
(\mathrm{ft})\end{array}$ & $\begin{array}{c}\text { Base Depth } \\
(\mathrm{ft})\end{array}$ \\
\hline 4 & 0.26 & 0 & 47 \\
\hline & & & \\
\hline
\end{tabular}

RLS Passive Spectral Gamma Survey Information

\begin{tabular}{|c|c|c|c|c|c|}
\hline \multicolumn{6}{|c|}{$\begin{array}{l}\text { Logging Engineers } \frac{R . V . C r a m}{} \\
\text { Log Depth Reference at Zero (0.0) }\end{array} \frac{S . E \text {. E. Kos }}{\text { depth is Ground Level }}$} \\
\hline Log Date & $\begin{array}{l}\text { Archive } \\
\text { File Names }\end{array}$ & Log Mode 1 Speed & $\begin{array}{l}\text { Depth } \\
\text { Top }\end{array}$ & $\begin{array}{l}\text { Interva } \\
\text { Base }\end{array}$ & $\begin{array}{l}\text { (ft) } \\
\text { Incr }\end{array}$ \\
\hline \multirow[t]{2}{*}{ Sept $30,9 ?$} & GP05 \A256 & $80 \mathrm{sec}$ LT & 0 & 20 & 0.5 \\
\hline & & $80 \mathrm{sec} R T$ & 20 & 24 & 0.5 \\
\hline
\end{tabular}

Calibration and Analysis Information

RLS Calibration Date: Nov 21, 1991

Calibration Report: WHC-SD-EN-TRP-001

Analyst Names: J.P. Kiesler

Analys is Date: 0ct 12.1992

Analysis Notes: Bend in casing restricted survey depth to $24 \mathrm{ft}$.

Radionuc]ides identified: $\mathrm{Cs}-137$ 
WHC-SD-EN-TI-257, Rev. 0

\section{RLS Borehole Survey Report}

\section{GP-5 Cone Penetrometer}

$\begin{array}{llll}\text { Casing } & \text { Depth: } 47 \mathrm{ft} & \text { Size: } 4^{\prime \prime} & \text { Thickness: } 0.26 \mathrm{in} \\ \text { Water } & \text { Depth: none } & & \\ \text { Survey } & \text { Depth: } 0-20 \mathrm{ft} & \text { Mode: MSA 80 } & \\ & & 20-24 \mathrm{ft} & \text { Mode: MSA 80 }\end{array}$

\section{General Notes:}

The hole was only logged to 24 feet, hole conditions would not permit the sonde to pass further down.

Log acquisition was switched from the standard counting configuration to Gated Integrator with $0.25 \mathrm{\mu sec}$ shaping when gross gamma activity approched 40,000 counts per second at $20 \mathrm{ft}$.

Gamma activity saturated the logging system from 21 feet to maximum survey depth of 24 feet.

Man-made Radionuclides:

Cesium (Cs-137) was encountered from 0 feet to 3 feet and 18 feet to 24 feet. Maximum decay activity exceeded $5000 \mathrm{pCi} / \mathrm{g}$ from 21 to 24 feet and $200 \mathrm{pCi} / \mathrm{g}$ at 20 feet. The cesium activity indicated from 0 feet to 3 feet is less than 6 $\mathrm{pCi} / \mathrm{g}$.

No Cobalt $(\mathrm{Co}-60)$ was encountered in the borehole. The plot track is present only for uniformity of the displayed data.

No Antimony $(5 b-125)$ was encountered in the borehole. The plot track is present oniy for uniformity of the displayed data.

No Europium-154 (Eu-154) was encountered in the borehole. The plot track is present only for uniformity of the displayed data. 
WHC-SD-EN-TI-257, Rev. 0

\section{RLS Spectral Gamma-Ray Borehole Survey}

Project: Cone Penetrometer Borehole: GP-05
Log Date: Sep 30, 92

Anal. Date: Oct 12, 92

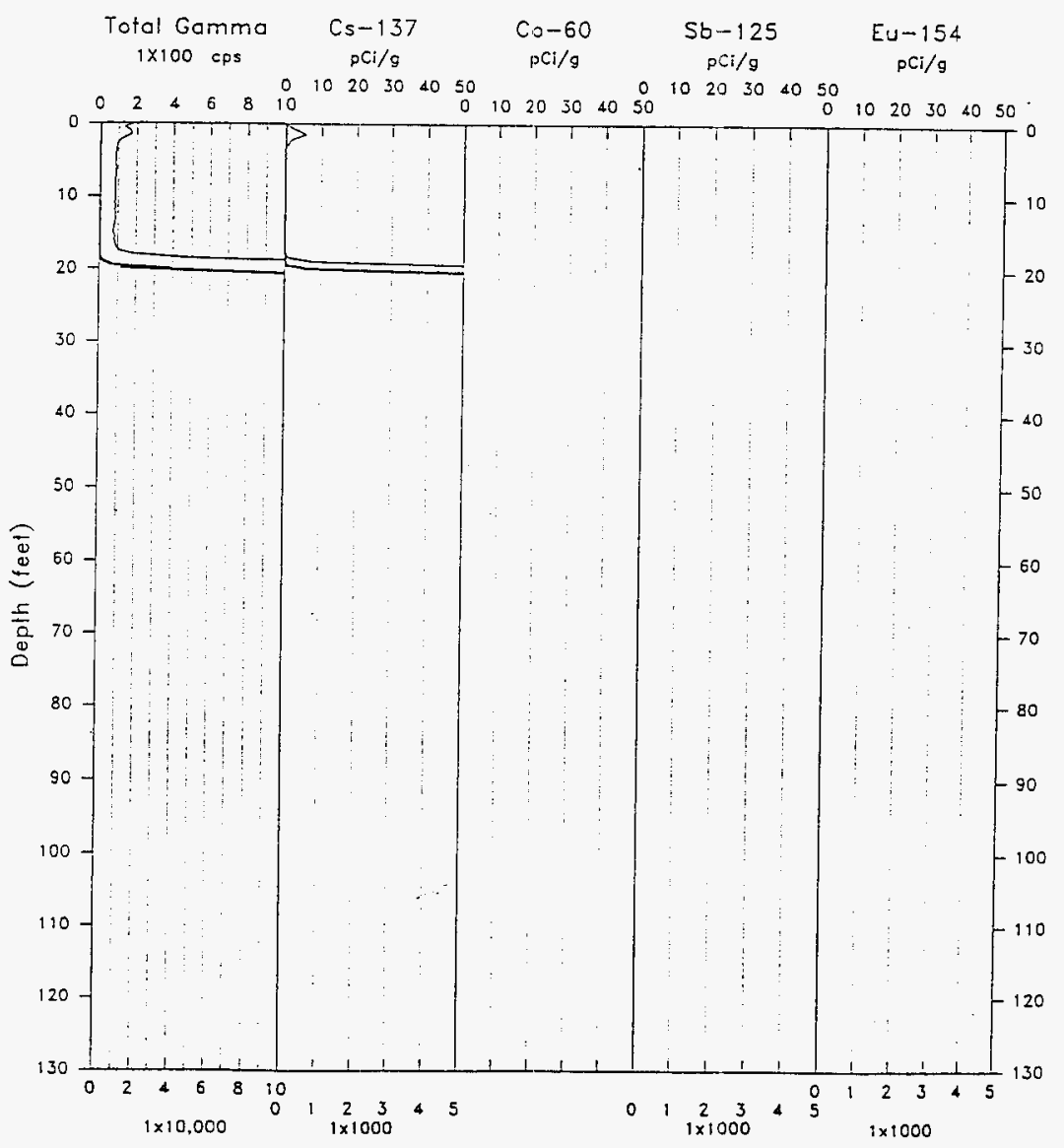




\section{WHC-SD-EN-TI-257, Rev 0}

This page intentionally left blank.

A-6 
WHC-SD-EN-TI-257, Rev 0

APPENDIX B

RLS Survey Data

B-1 


\section{WHC-SD-EN-TI-257, Rev 0}

This page intentionally left blank.

B-2 
WHC-SD-EN-TI-257, Rev. 0

Westinghouse Hanford Company

RLS Spectral Gamma-Ray Borehole Survey Log Header

Project: 200 BP -1

\begin{tabular}{|c|c|c|c|}
\hline Bore & $C P-6$ & & \\
\hline $\begin{array}{l}\text { Coordinates } \\
\text { Elevation }\end{array}$ & $\frac{N A}{N A} \mathrm{ft}$ & $\begin{array}{l}\text { NA } W \\
\text { Top of casing }\end{array}$ & $\begin{array}{l}\text { (Hanford } 200 \text { Area) } \\
\text { (Hanford } 200 \text { Area) }\end{array}$ \\
\hline
\end{tabular}

Borehole Environment Information

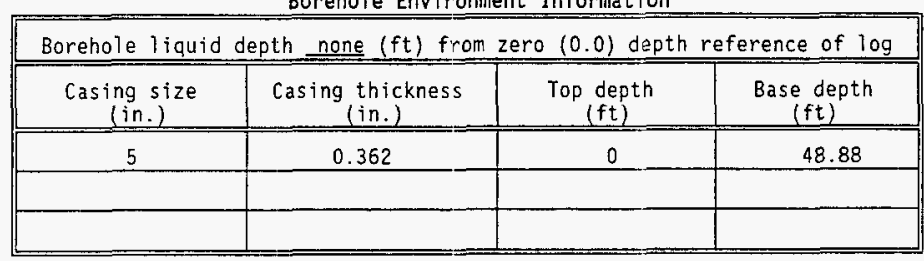

RLS Passive Spectral Gamma Survey Information

\begin{tabular}{|c|c|c|c|c|c|}
\hline \multicolumn{6}{|c|}{$\begin{array}{l}\text { Logging Engineers } \frac{R \text {. V. Cram }}{\text { Log depth reference at zero }(0.0)} \frac{\text { S. E. Kos }}{\text { depth is ground level }}\end{array}$} \\
\hline Log Date & $\begin{array}{l}\text { Archive } \\
\text { file names }\end{array}$ & Log mode speed & $\begin{array}{c}\text { Deptr } \\
\text { Top }\end{array}$ & $\begin{array}{l}\text { interval } \\
\text { Base }\end{array}$ & $\begin{array}{l}\text { (ft) } \\
\text { Incr }\end{array}$ \\
\hline \multirow[t]{2}{*}{ Mar 05, 1993} & CPO6\\
339 & MSA $80 \mathrm{sec}$ RT & 0 & 12.5 & 0.5 \\
\hline & & Stat: on $300 \mathrm{sec}$ & & 12.4 & \\
\hline & & & & & \\
\hline
\end{tabular}

Calibration and Analysis Information

RLS Calibration Date: Nov. 2i, 1991

Calibration Report: WHC-SD-EN-TRP-001

Analyst Names: W. F. Nicaise

Analysis Date: Mar 10, 1993

Analys is Notes:

Radionuclides Identified: Natural only.

B- 3 
WHC-SD-EN-TI-257, Rev. 0

\section{RLS Spectral Gamma-Ray Borehole Survey}

Project: 200-BP-1

Borehole: $\mathrm{CP}-6$
Log Date: Mar 05, 1993

Anal. Date: Mar 10, 1993

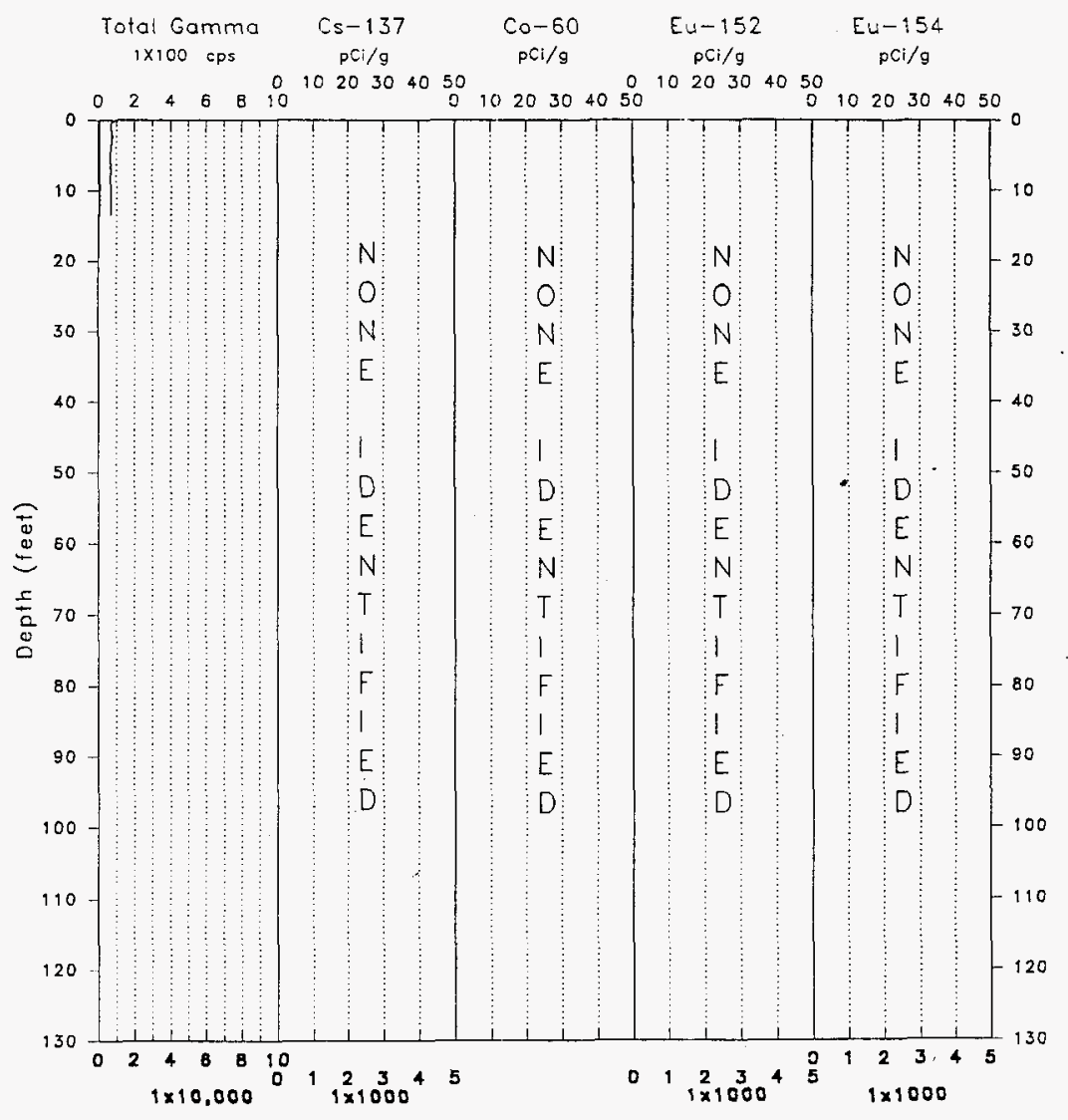

B-4 
WHC-SD-EN-TI-257, Rev. 0

\begin{abstract}
RLS Spectral Gamma-Ray Borehole Survey
Project: 200-BP-1

Log Date : Mar 05, 1993

Borehole : CP-6

Anal Date: Mar10, 1993
\end{abstract}

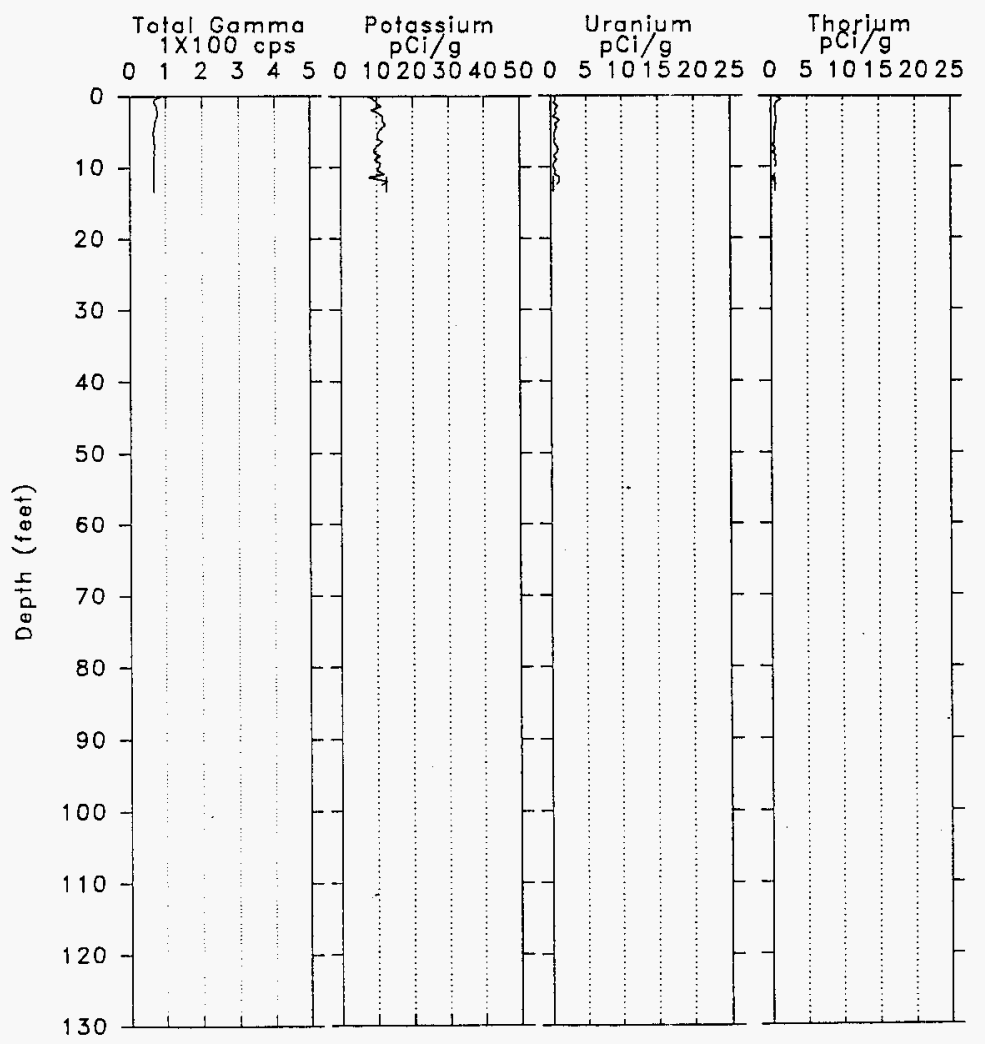


WHC-SD-EN-TI-257, Rev. 0

\section{RLS BorehoTe Survey Report}

Borehole: $C P-6$

$\begin{array}{llll}\text { Casing } & \text { Depth: } 48.88^{\prime} & \text { Size: } 5^{\prime \prime} & \text { Thickness: 0.362" } \\ \text { Water } & \text { Depth: none } & & \\ \text { Survey } & \text { Depth: } 0-12.5^{\prime} & \text { Date: 03/05/93 } & \\ & \text { Stations: } 12.4^{\prime} & & \end{array}$

General Notes:

The well was monitored at fixed intervals from 0 to 12.5 feet at fixed intervals of 0.5 feet, for real time counting intervals of 80 seconds. In addition the well was monitored at the fixed depth of 12.4 feet for a real time counting interval of 300 seconds. The only radionuclides detected were naturally occurring potassium, uranium, and thorium. These radionuclides were found to be present with calculated activities which are normal for Hanford soils, as is shown on the second plot. The first plot of man-made radionuclides, in which no radionuclides are shown detected, is included for uniformity of presentation only.

A slight elevation in the total gamma ray count rate can be observed at the surface level of the well. That the count rate drops immediately as the probe enters the subsurface indicates that the activity observed is not associated with the soil formation surrounding the well. Rather it must be a surface phenomenon, perhaps due to some slight surface contamination, or shine from a nearby above surface structure.

Man-made Radionuclides:

No man-made radionuclides observed. 
WHC-SD-EN-TI-257, Rev. 0

\section{Westinghouse Hanford Company \\ RLS Spectral Gamma-Ray Borehole Survey Log Header}

Project: $200 \mathrm{BP}-1$

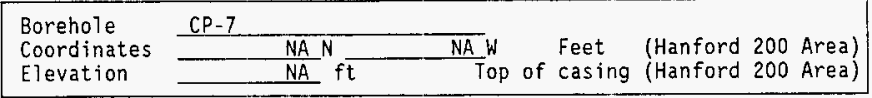

Borehole Environment Information

\begin{tabular}{|c|c|c|c|}
\hline \begin{tabular}{c} 
Borehole liquid depth none (ft) from zero (0.0) depth reference of log \\
\hline \hline $\begin{array}{c}\text { Casing size } \\
\text { (in.) }\end{array}$
\end{tabular} Casing thickness & $\begin{array}{c}\text { Top deptr } \\
\text { (in.) }\end{array}$ & $\begin{array}{c}\text { Base depth } \\
\text { (ft) }\end{array}$ \\
\hline 5 & 0.362 & 0 & 47.5 \\
\hline & & & \\
\hline & & & \\
\hline
\end{tabular}

RLS Passive Spectral Gamma Survey Information

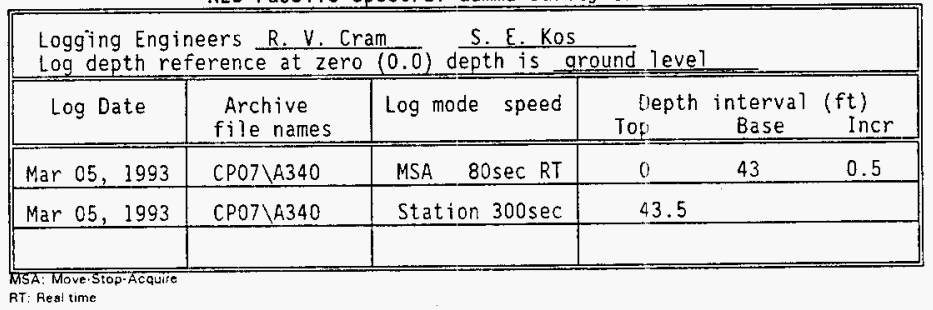

Calibration and Analysis Information

RLS Calibration Date: Nov. 21, 1991

Calibration Report: WHC-SD-EN-TRP-001

Analyst Names: W. F. Nicaise

Analysis Date: Mar.24, 1993

Analysis Notes:

Radionuclides Identified: $\quad$ Cs-137 
WHC-SD-EN-TI-257, Rev. 0

RLS Spectral Gamma-Ray Borehole Survey

Project: $200 \mathrm{BP}-1$

Borehole: $\mathrm{CP}-7$
Log Date: Mar 05, 1993

Anal. Date: Mar 24, 1993

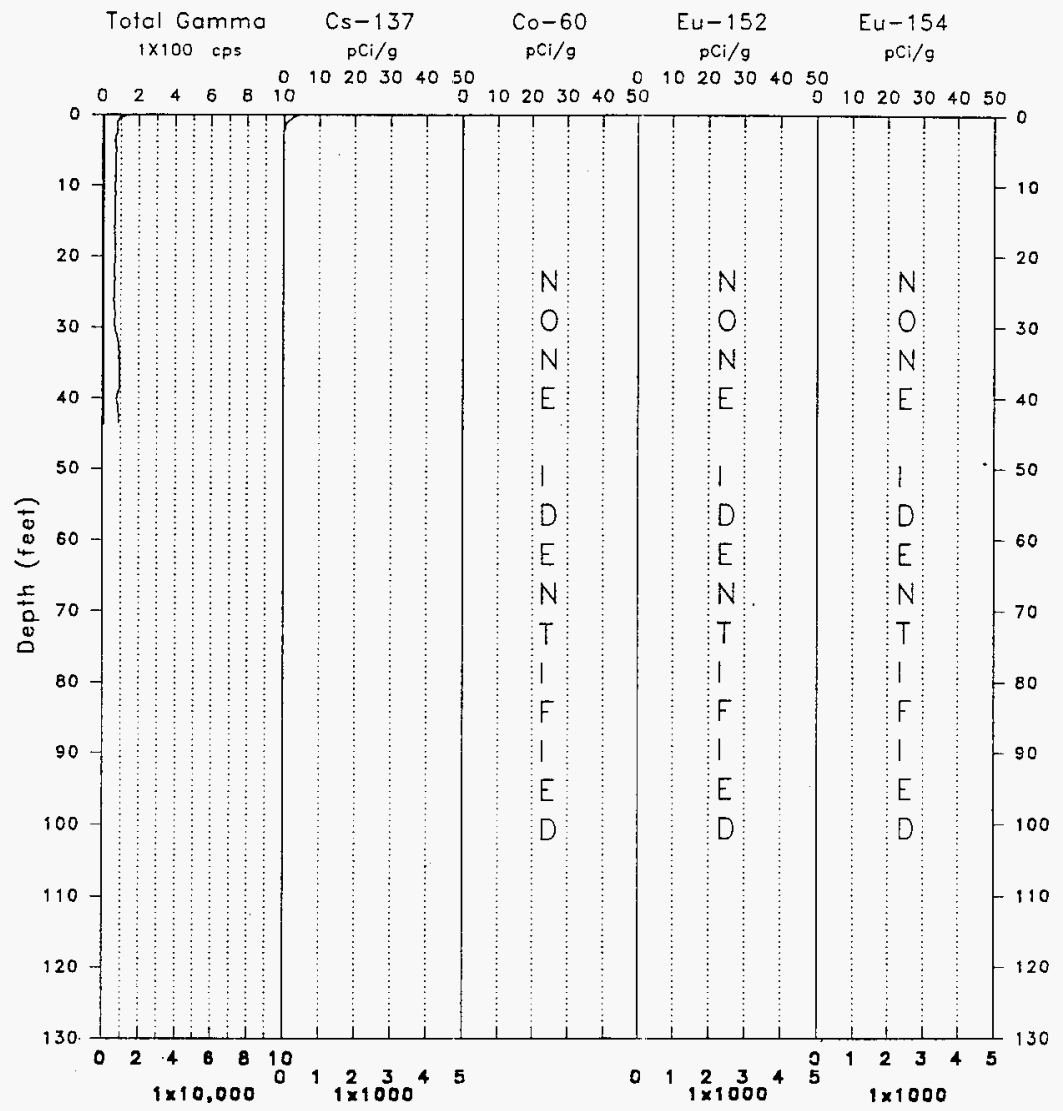


WHC-SD-EN-TI-257, Rev. 0

RLS Spectral Gamma-Ray Borehole Survey

Project: $200 \mathrm{BP}-1$

Borehole : $\mathrm{CP}-7$
Log Date: Mar 05, 1993

Anal Date: Mar 24, 1993

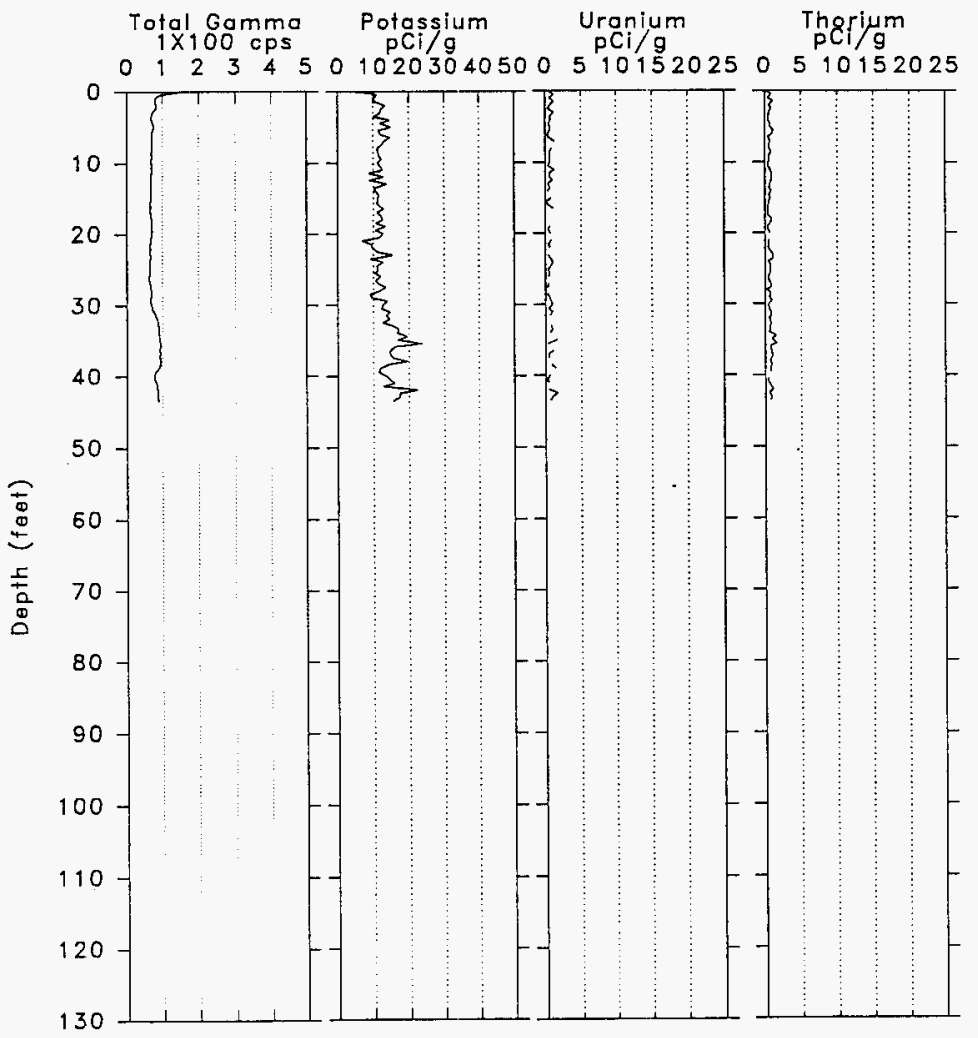


WHC-SD-EN-TI-257, Rev. 0

\section{RLS Borehole: Survey Report}

Borehole: CP-7.

$\begin{array}{llll}\text { Casing } & \text { Depth: } 47.5^{\prime} & \text { Size: } 5 " & \text { Thickness: } 0.362^{\prime \prime} \\ \text { Water } & \text { Depth: none } & & \\ \text { Survey } & \text { Depth: } 0-43.5^{\prime} & \text { Date: } 3 / 05 / 93 & \\ & \text { Stations: } 43.5^{\prime} & & \end{array}$

Generai Notes:

The well was monitored at fixed intervals from 0 to 43.5 feet, in increments of 0.5 feet, for real counting periods of 80 seconds. The well was also monitored at the fixed depth of 43.5 feet for a rea 7 counting time of 300 seconds. As shown on the first plot the total gamma ray count rate is slightly elevated near ground level. This coincides with a similar region of activity which was observed due to the man-made radionuclide Cesium-137, from ground level to a depth of two feet. No other man-made radionuclides were observed. Although there is insufficient data at present to come to any definite conclusion regarding the source of this radionuclide, the depth profile of its activity is similar to that which would be expected for surface contamination which has diffused into undisturbed soil over time.

The naturally occurring radionuclides of potassium, uranium, and thorium are observed at activities which are normal for Hanford soils. These activities are shown on the second plot.

Manmade Radionuclides:

Cesium (Cs-137) was detected from ground level to two feet. The maximum calculated activity of $4 \mathrm{pCi} / \mathrm{g}$ occurred at the surface.

No Cobalt (Co-60) was detected. The template is presented for uniformity of presentation only.

No Europium (Eu-154) was detected. The template is presented for uniformity of presentation only.

No Europium (Eu-152) was detected. The template is presented for uniformity of presentation only. 


\section{Westinghouse Hanford Company RLS Spectral Gamma-Ray Borehole Survey Log Header}

Project: $200 \mathrm{BP}-1$

$\begin{array}{llll}\text { Borehole } & C P-8 & & \\ \text { Coordinates } \\ \text { Elevation }\end{array}$

Borehole Environment Information

\begin{tabular}{|c|c|c|c|}
\hline Borehole liquid depth none (ft) from zero (0.0) depth reference of log \\
\hline $\begin{array}{c}\text { Casing size } \\
\text { (in.) }\end{array}$ & $\begin{array}{c}\text { Casing thickness } \\
\text { (in.) }\end{array}$ & $\begin{array}{c}\text { Top depth } \\
(\mathrm{ft})\end{array}$ & $\begin{array}{c}\text { Base depth } \\
\text { (ft) }\end{array}$ \\
\hline 5 & 0.375 & 0 & 46.2 \\
\hline & & & \\
\hline
\end{tabular}

\section{RLS Passive Spectral Gamma Survey Information}

Logging Engineers J. P. Kiesler S. E. Kos Log depth reference at zero $(0.0)$ depth is ground leve?

\begin{tabular}{||c|c|c|ccc||}
\hline Log Date & $\begin{array}{c}\text { Archive } \\
\text { file names }\end{array}$ & Log mode speed & \multicolumn{3}{c||}{$\begin{array}{c}\text { Depth interval (ft) } \\
\text { Top }\end{array}$} \\
\hline \hline Mar 08, 1993 & CP08\A342 & MSA 80sec RT & 0 & 18.5 & 0.5 \\
\hline & & Station 300sec & 18.7 & & \\
\hline & & & & & \\
\hline
\end{tabular}

Calibration and Analysis Information

RL.S Calibration Date: Nov. 21, 1991

Calibration Report: WHC-SD-EN-TRP-001

Analyst Names: W. F. Nicaise R.K.Price

Analysis Date: Mar. 15, 1993

Analysis Notes:

Radionuclides Identified: CS-137 
WHC-SD-EN-T1-257, Rev. 0

\section{RLS Spectral Gamma-Ray Borehole Survey}

Project: $200 \mathrm{BP}-1$

Borehole: $\mathrm{CP}-8$

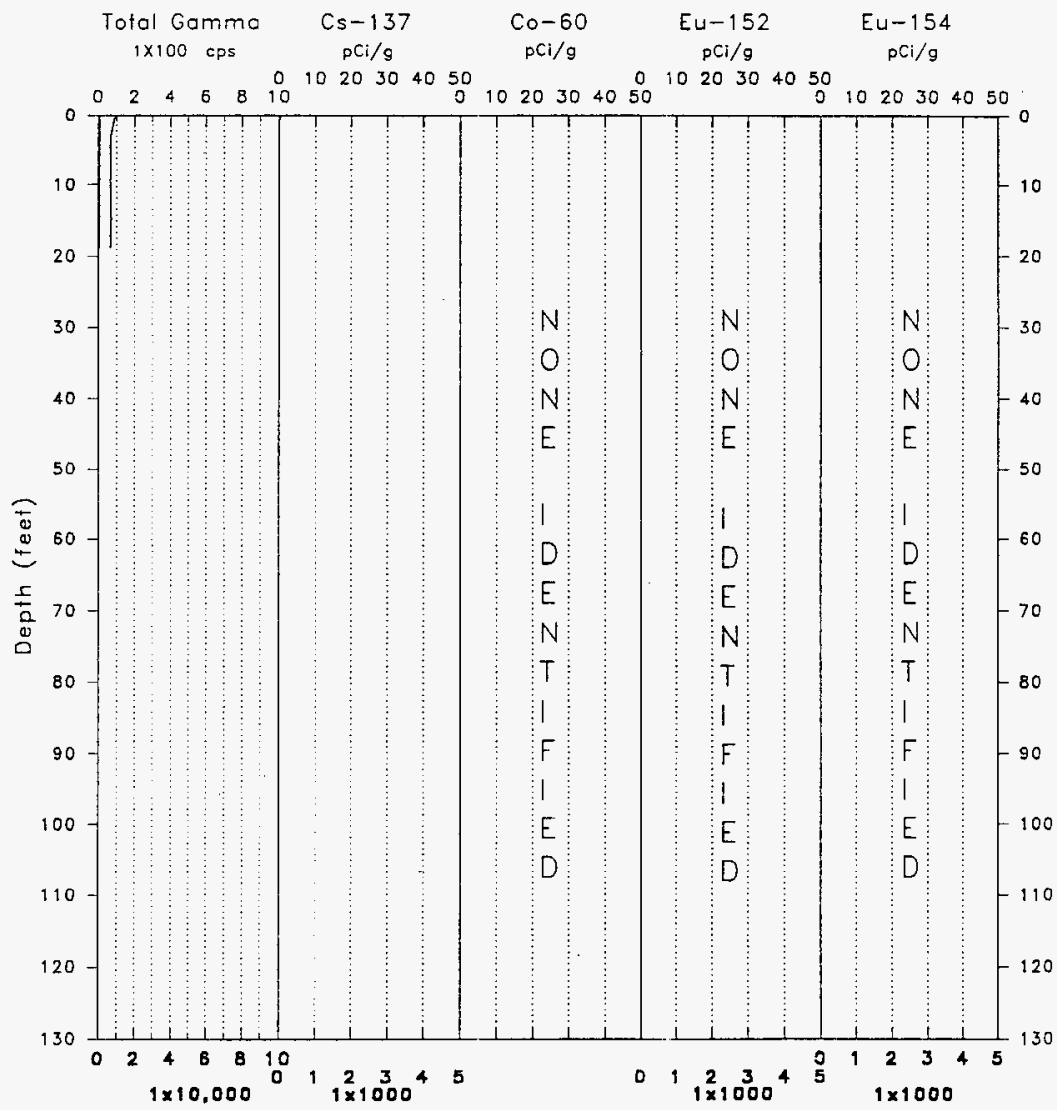

Log Date: Mar 08, 1993 Anal. Date: Mar 15, 1993 
WHC-SD-EN-TI-257, Rev. 0
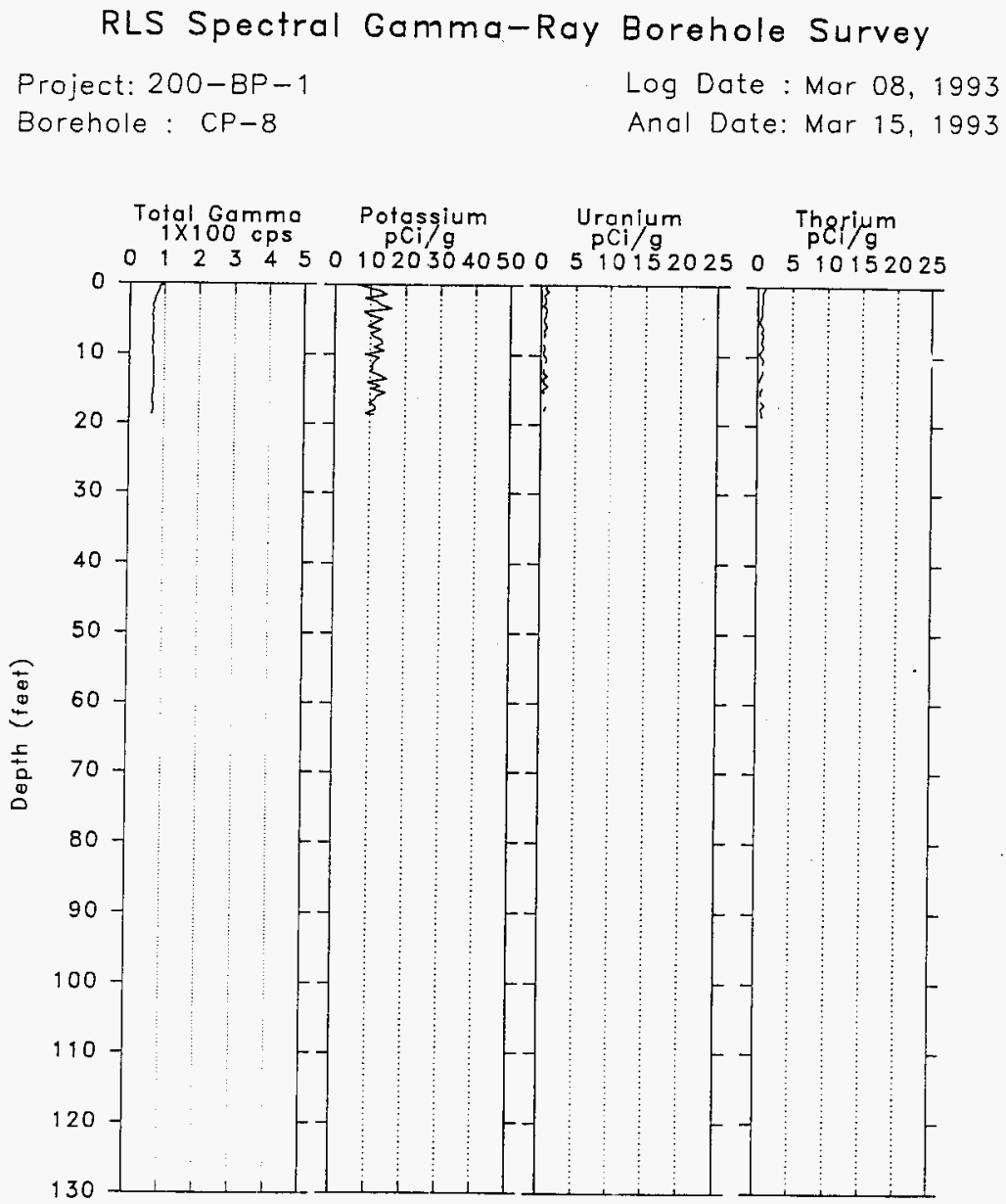
WHC-SD-EN-TI-257, Rev. 0

\section{RLS Borehole Survey Report}

Borehole: $\mathrm{CP}-8$

Casing Depth: 46.2' Size: 5" Thickness: $0.375^{\prime \prime}$

Water Depth: none

Survey Depth: 0 - 18.7' Date: 3/08/93

Stations: $18.7^{\prime}$

Generai Notes:

It was planned to monitor the well at fixed intervais from 0 to 43 feet at increments of 0.5 feet, for real tine counting intervals of 80 seconds. However the casing was kinked such that it was not possible to monitor the well with the RLS borehole sonde below a depth of 18.7 feet. An additional measurement was taken at 18.7 feet for a real time counting interval of 300 seconds.

The only man-made radionuclide observed is Cesium-137, which was found to be present in the first one half foot of soil. The calculated activity of this radionuclide varied from approximately $0.7 \mathrm{pCi} / \mathrm{g}$ at the surface to $0.2 \mathrm{pCi} / \mathrm{g}$ at 0.5 feet. Although there is insufficient data at present to come to any definite conclusions regarding this radionuclide, the depth profile of the activity is similar to that which would be expected for surface contamination which has diffused into undisturbed soil over time. The activity profile is shown on the first plot.

The naturally occurring radionuclices of potassium, uranium, and thorium are abserved at activities which are ncrmal for Hanford soils. These activities are shown on the second plot.

Manmade Radionuclides:

Cesium (Cs-137) was detected from zero to 0.5 feet. The maximum calculated activity of this radionuclide is less than $1 \mathrm{pCi} / \mathrm{g}$, occurring at the surface.

No Cobalt (CO-60) was detected. The template is presented for uniformity of presentation only.

No Europium (Eu-154) was detected. The template is presented for uniformity of presentation only.

No Europium (Eu-152) was detected. The template is presented for uniformity of presentation only. 
WHC-SD-JEN-TI-257, Rev. 0

\section{Westinghouse Hanford Company \\ RLS Spectral Gamma-Ray Borehole Survey Log Header}

Project: $200 \mathrm{BP}-1$

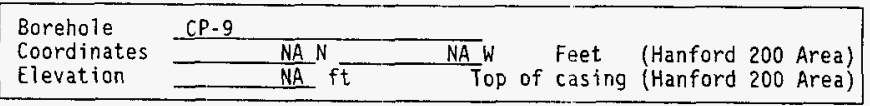

Borehole Environment Information

\begin{tabular}{|c|c|c|c|}
\hline Borehole liquid depth none (ft) from zero (0.0) depth reference of log \\
\hline $\begin{array}{c}\text { Casing size } \\
\text { (in.) }\end{array}$ & $\begin{array}{c}\text { Casing thickness } \\
\text { (in.) }\end{array}$ & $\begin{array}{c}\text { Top depth } \\
\text { (ft) }\end{array}$ & $\begin{array}{c}\text { Base depth } \\
\text { (ft) }\end{array}$ \\
\hline 5 & 0.375 & 0 & 49.2 \\
\hline & & & \\
\hline
\end{tabular}

RLS Passive Spectral Gamma Survey Information

\begin{tabular}{|c|c|c|c|c|}
\hline \multicolumn{5}{|c|}{$\begin{array}{l}\text { Logging Engineers } \frac{R . V . C r a m}{\text { L. Cro }} \\
\text { Log depth reference at zero }(0.0)\end{array}$} \\
\hline Log Date & $\begin{array}{l}\text { Archive } \\
\text { file names }\end{array}$ & Log mode speed & $\begin{array}{l}\text { Depth interva } \\
\text { Top Base }\end{array}$ & $\begin{array}{l}\text { ft) } \\
\text { Incr }\end{array}$ \\
\hline Mar 10, 1993 & $C P 09 \backslash A 343$ & $80 \mathrm{sec}$ RT & 46.5 & 0.5 \\
\hline Mar 10, 1993 & $C P 09 \backslash A 343$ & Station $300 \mathrm{sec}$ & $32^{\prime}, 46.5^{\prime}$ & \\
\hline
\end{tabular}

RT: Real time

\section{Calibration and Analys is Information}

RLS Calibration Date: Nov. 21, 1993

Calibration Report: WHC-SD-EN-TRPP-001

Analyst Names: W. F. Nicaise R. K. Price

Analysis Date: Mar. 18, 1993

Analysis Notes:

Radionuclides Identified: Cs-137 
WHC-SD-EN-TI-257, Rev. 0

RLS Spectral Gamma-Ray Borehole Survey

Project: $200 \mathrm{BP}-1$
Borehole: $\mathrm{CP}-9$
Log Date: Mar 10, 1993

Anal. Date: Mar 18, 1993

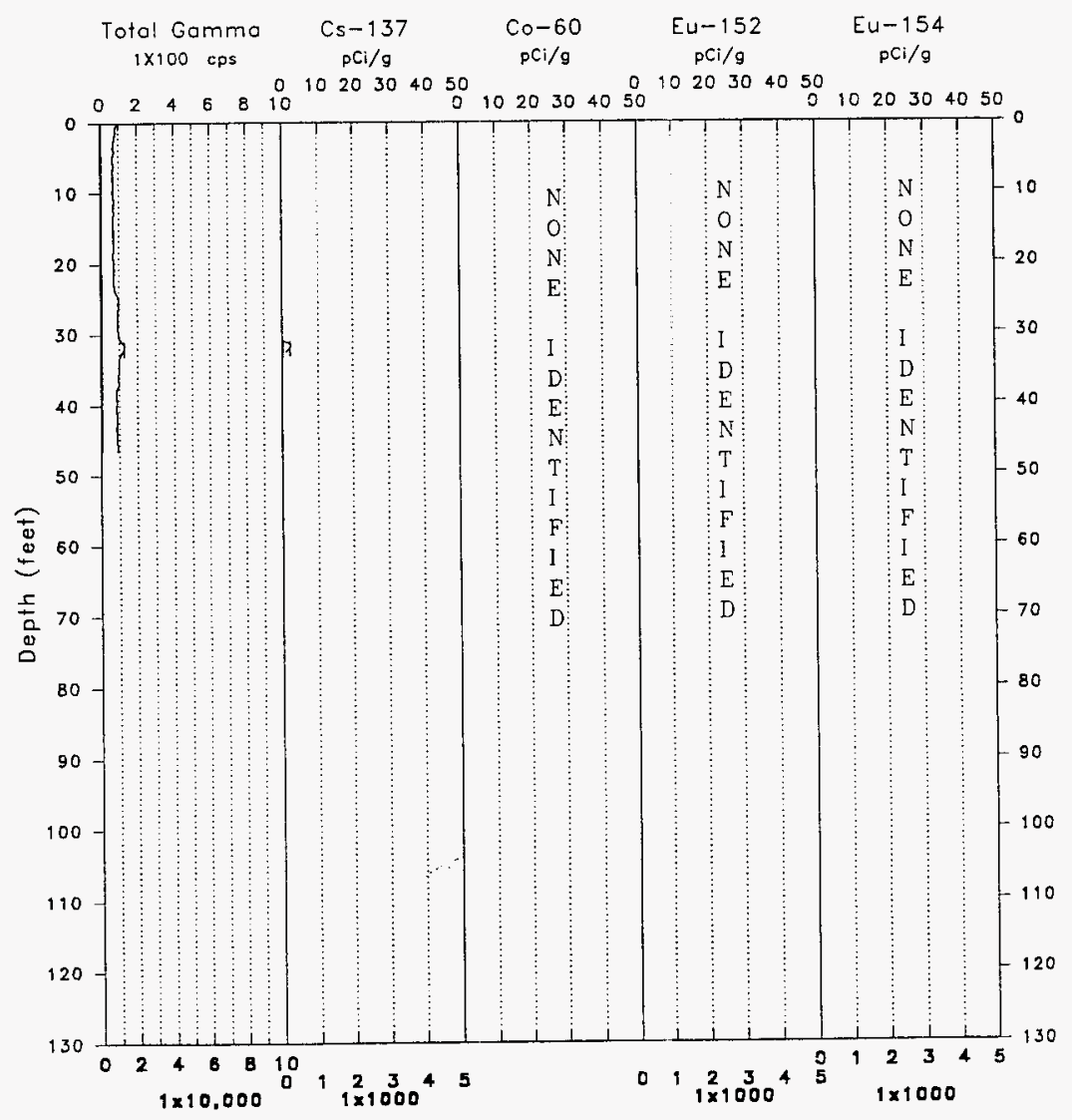

B- 15 
RLS Spectral Gamma-Ray Borehole Survey

Project: $200 \mathrm{BP}-1$

Borehole : CP-9
Log Date : Mar 10, 1993

Anal Dote: Mar 18, 1993

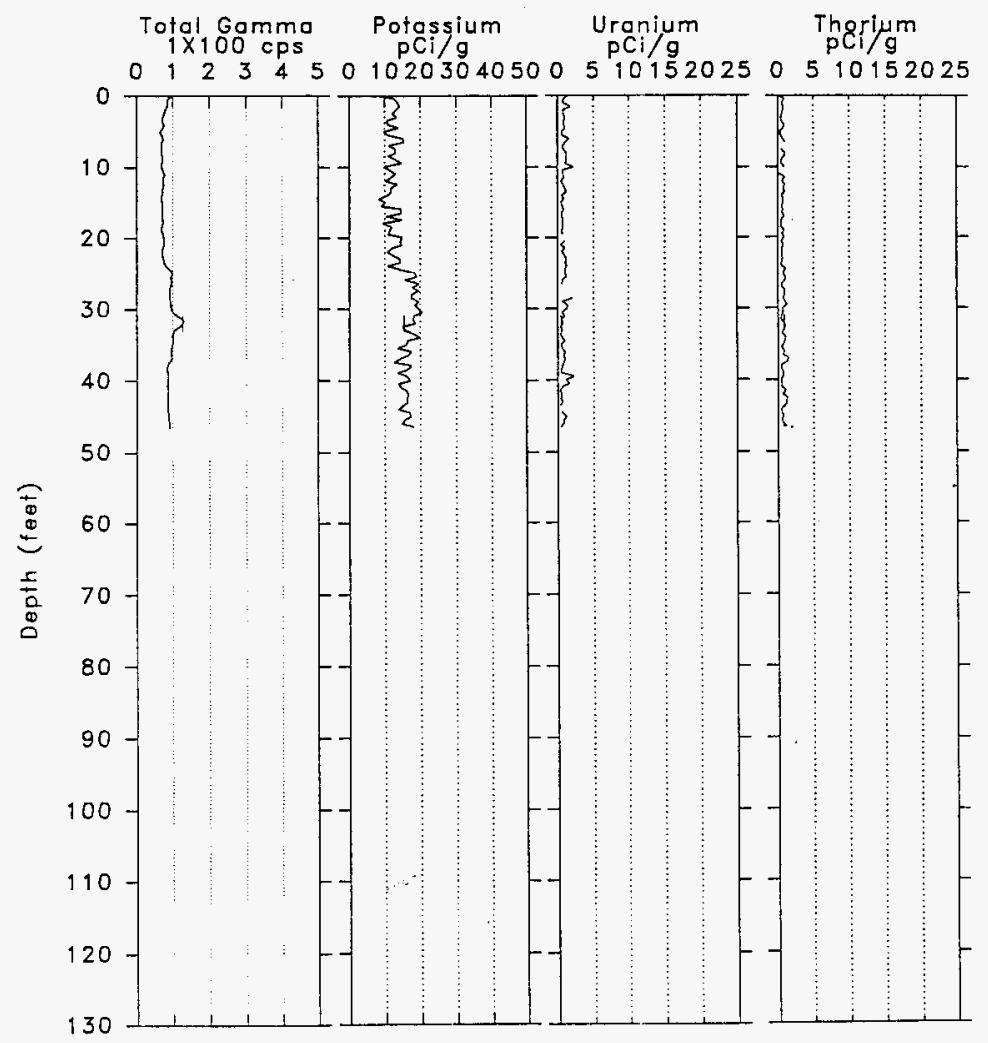

B- 16 
WHC-SD-EN-TI-257, Rev, 0

\section{RLS Borehole Survey Report}

Borehole: $\underline{C P-9}$

$\begin{array}{llll}\text { Casing } & \text { Depth: 49.2' } & \text { Size: 5" } & \text { Thickness: } 0.375^{\prime \prime} \\ \text { Water } & \text { Depth: none } & & \\ \text { Survey } & \text { Depth: } 00{ }^{\prime} 46.5^{\prime} & \text { Date: } 03 / 10 / 93 & \\ & \text { Stations: } 32^{\prime}, 46.5^{\prime} & & \end{array}$

General Notes:

The well was monitored at fixed intervals from 0 to 46.5 feet, in increments of 0.5 feet, for real counting periods of 80 seconds. The we11 was also monitored at the fixed depths of 32 and 46.5 feet for real counting times of 300 seconds. The total gamma count rate shows a slightly elevated activity in the range from 31 to 33 feet. This coincides with a similar region of activity which was observed due to the man-made radionuclide Cesium (Cs-137) centered at a depth of about 32 feet. No other man-made radionuclides were observed. These data are shown on the first plot. The naturally occurring radionuclides potassium, uranium, and thorium were also observed at activities which are normal for Hanford soils. These activities are shown on the second plot.

Man-made Radionuclides:

Cesium (Cs-137) was detected from 31 to 33 feet. The maximum concentration of $3 \mathrm{pC} / \mathrm{g}$ occurred at a depth of 32 feet.

No Cobalt (Co-60) was detected. The template is presented for uniformity of presentation only.

No Europium (Eu-154) was detected. The template is presented for uniformity of presentation only.

No Europium (Eu-152) was detected. The template is presented for uniformity of presentation only. 
WHC-SD-EN-T1-257, Rev 0

APF'ENDIX C

RLS Data for Other Holes in the Vicinity of Crib 216-B-57

C-1 
WHC-SD-EN-TI-257, Rev 0

This page intentionally left blank.

C. 2 
WHC-SD-EN-TI-257, Rev. 0

\section{Westinghouse Hanford Company RLS Spectral Gamma-Ray Borehole Survey Log Header}

Project: $200-8 P-1$, 216-B-47 Crib

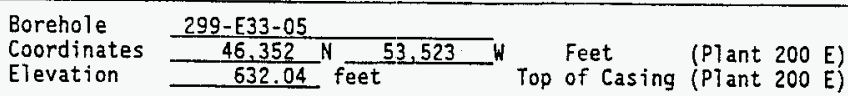

Borehole Environment Information

\begin{tabular}{|c|c|c|c|}
\hline \hline Borehole Fluid Depth 224 (Feet) from Zero (0.0) Depth Reference of Log \\
\hline \hline $\begin{array}{c}\text { Casing Size } \\
\text { I.D. (inch) }\end{array}$ & $\begin{array}{c}\text { Casing Thickness } \\
\text { (inch) }\end{array}$ & $\begin{array}{c}\text { Top Depth } \\
\text { (feet) }\end{array}$ & $\begin{array}{c}\text { Base Depth } \\
\text { (feet) }\end{array}$ \\
\hline \hline 8 & 0.312 & 0.0 & 236.0 \\
\hline 4 & 0.188 & 0.0 & 214.0 \\
\hline
\end{tabular}

RLS Passive Spectral Garmina Survey Information

\begin{tabular}{|c|c|c|c|c|c|}
\hline \multicolumn{6}{|c|}{$\begin{array}{l}\text { Logging Engineers }- \text { R. V.Cram } \\
\text { Log Depth Reference at Zero (0.0) }\end{array}$} \\
\hline Log Date & $\begin{array}{l}\text { Archive } \\
\text { File Names } \\
\end{array}$ & Log Mode, Speed & $\begin{array}{l}\text { Depth } \\
\text { Top }\end{array}$ & $\begin{array}{c}\text { Interval } \\
\text { Base } \\
\end{array}$ & $\begin{array}{r}\text { (feet) } \\
\text { Incr }\end{array}$ \\
\hline Sept 12,91 & $\mathrm{H} 2 \mathrm{E} 3305 \backslash \mathrm{A} 072$ & FIXED $1.5 \mathrm{fpm}$ & 0.0 & 132.0 & 0.5 \\
\hline Sept 18,91 & H2E3305\A075 & FIXED $0.8 \mathrm{fpm}$ & 0.0 & 106.0 & 0.5 \\
\hline Sept 18,91 & H2E3305\A076 & FIXED $\quad 0.8 \mathrm{fpm}$ & 98.0 & 173.0 & 0.5 \\
\hline Sept 18,91 & H2E3305\A077 & FIXED $0.8 \mathrm{fpm}$ & 150.0 & 236.0 & 0.5 \\
\hline
\end{tabular}

Calibration and Analysis information

\begin{tabular}{|c|c|c|}
\hline \multicolumn{3}{|c|}{$\begin{array}{l}\text { RLS Calibration Date: Nov } 21,199] \\
\text { Calibration Report: }\end{array}$} \\
\hline $\begin{array}{l}\text { Analyst Names: } \\
\text { Analysis Date: }\end{array}$ & $\frac{\text { J. P. Kies Ter }}{\text { Sept } 01,1992}$ & R. K. Price \\
\hline $\begin{array}{l}\text { Analysis Notes: } \\
\text { Radionuclides ic }\end{array}$ & $\frac{\text { Two survey scan }}{\text { dentified: } C_{5-1}}$ & $\frac{132^{\prime} \text { demonstrate good repeatibility }}{\mathrm{C}_{0}-60, \mathrm{Sb}-125}$ \\
\hline
\end{tabular}

C. 3 


\section{RLS Spectral Gamma-Ray Borehole Survey}

Project: 200-BP-1

Borehole: 299-E33-5
Log Date: Sept 18, 91

Anal. Date: Sep 1,92

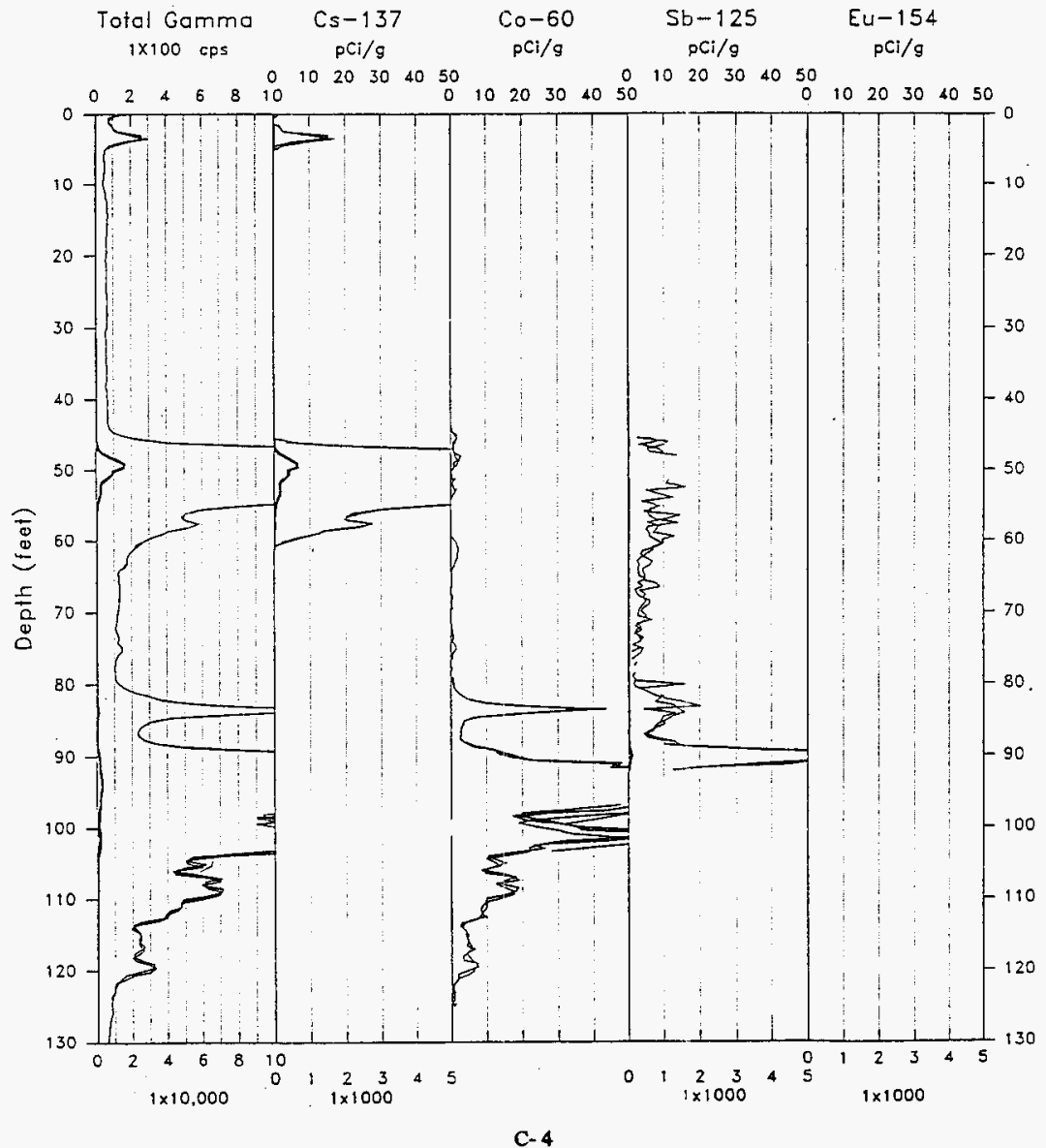




\section{RLS Spectral Gamma-Ray Borehole Survey}

Project: 200-BP-1

Borehole: 299-E33-5
Log Date: Sep 18, 91

Anal. Date: Sep 1, 92

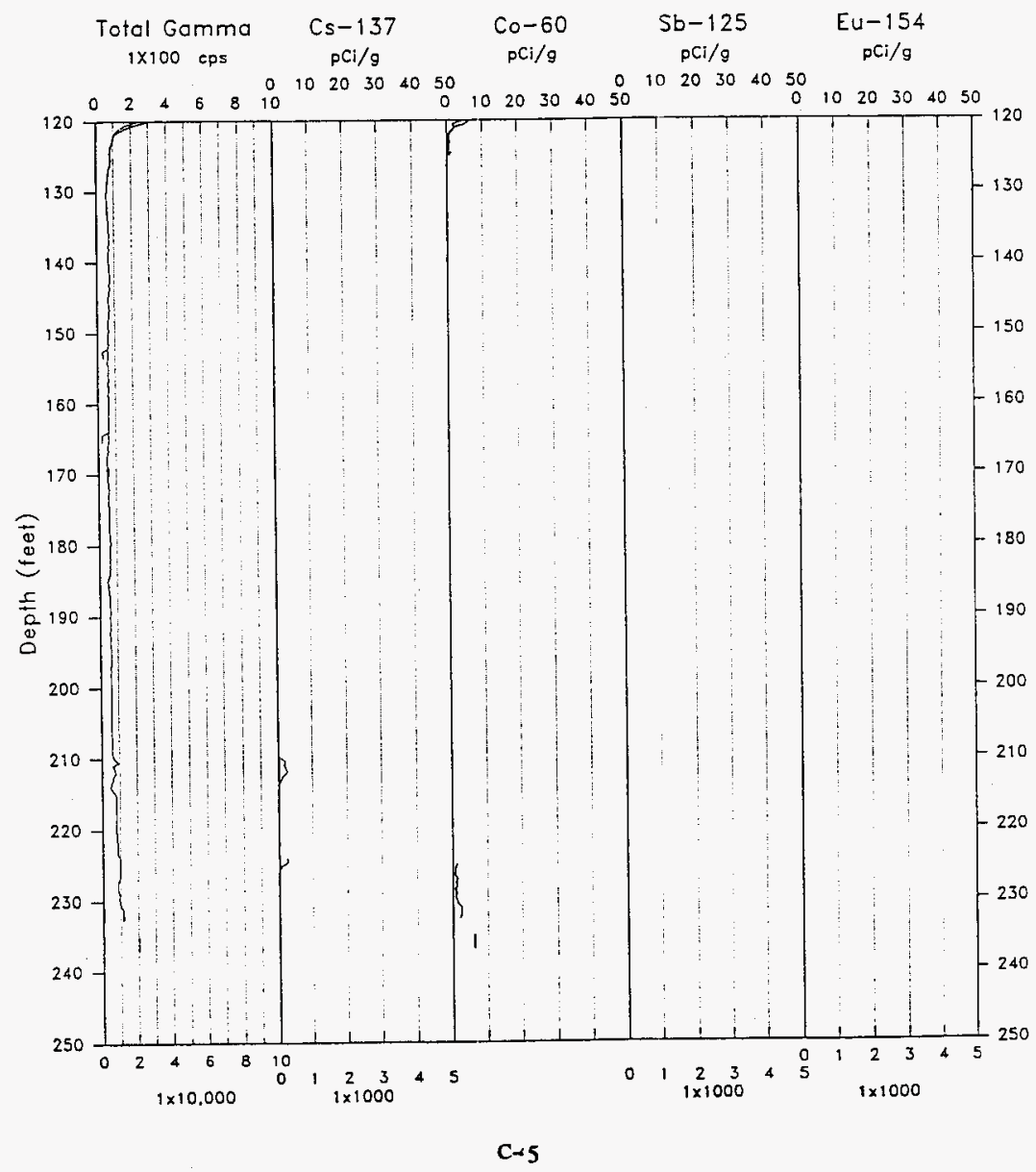


WHC-SD-EIN-TI-257, Rev. 0

RLS Borehole: Survey Report

299-E33-05_216-B-47 Crib

$\begin{array}{lllll}\text { Casing Depth: } 234 \mathrm{ft} . & \text { Size: } 8 \mathrm{in} . & \text { Thickness: } 0.313 \mathrm{in} . \\ & \text { Depth: } 214 \mathrm{ft} . & \text { Size: } 6 \mathrm{in} . & \text { Thickness: } 0.188 \mathrm{in} . \\ \text { Water } & \text { Depth: } 224 \mathrm{ft} . & & \\ \text { Survey } & \text { Depth: } 0-132 \mathrm{ft} . & \text { Date: } 9 / 12 / 91 & \\ & 0-106 \mathrm{ft} . & & 9 / 18 / 91 & \\ & 98-173 \mathrm{ft} . & 9 / 18 / 91 & \\ & 150-236 \mathrm{ft} . & 9 / 18 / 91 & \end{array}$

General Notes:

The data are plotted on two pages. The survey data from $120 \mathrm{ft}$ to $130 \mathrm{ft}$ are plotted on both pages.

The first $130 \mathrm{ft}$. were surveyed at two logging speeds to check system repeatability. The first $\log$ run $(0$ t:o $132 \mathrm{ft})$ was incorrectly started at the top of the casing ( $2 \mathrm{ft}$ above ground leve1) therefore a $2-\mathrm{ft}$. correction was applied for plotting. During the second survey, field problems forced restart of the computer program and reentry of the detector depth. The tool was repositioned at 98 feet for the third set of data. An overlap interval from $98 \mathrm{ft}$ to $106 \mathrm{ft}$ between data sets two and three identified a $1-\mathrm{ft}$ error then the depth was reentered. A minus $1-\mathrm{ft}$ correction has been applied to the third data set (98 to $173 \mathrm{ft}$.) for the $\log \mathrm{plot}$.

The maximum calibrated casing correction of $0.40 \mathrm{in}$. was applied to the survey data. The computed activity for data recorded through multiple casing strings will be underestimated.

The total gamma activity did not exceed $17,000 \mathrm{cps}$ in the borehole survey. Man-made Radionuclides:

Cesjum (Cs-137) was encountered in three intervals in the borehole: $0-7 \mathrm{ft}$., $48-63 \mathrm{ft}$ and $210-226 \mathrm{ft}$. The cesium decay activity exceeded $200 \mathrm{pCi} / \mathrm{g}$ from $50 \mathrm{ft}$ to $54 \mathrm{ft}$.

Cobalt $(\mathrm{CO}-60)$ was encountered in two intervals in the borehole from 46 to 127 $\mathrm{ft}$. and from 225 to $236 \mathrm{ft}$. The maximum decay activity detected was $90 \mathrm{pCi} / \mathrm{g}$ to $93 \mathrm{ft}$.

Antimony (Sb-125) was encountered in the borehole from $45 \mathrm{ft}$ to $92 \mathrm{ft}$. The maximum decay activity detected was $70 \mathrm{pCi} / \mathrm{g}$ at $90 \mathrm{ft}$.

No Europium-154 (Eu-154) was encountered in the borehole. The plot track is present only for uniformity of the displayed data. 


\section{Westinghouse Hanford Company \\ RLS Spectral Gamma-Ray Borehole Survey Log Header}

Project: 200 AAMS, 216-B-57 Crib

\begin{tabular}{|c|c|c|c|}
\hline $\begin{array}{l}\text { Borehole } \\
\text { Coordinates } \\
\text { Elevation }\end{array}$ & $\frac{\frac{299-E 33-24}{42.260}}{\frac{638.03}{2}} \mathrm{feet} \frac{53}{790}$ & $\begin{array}{l}\text { Feet } \\
\text { Top of Casing }\end{array}$ & $\begin{array}{l}(P l \text { ant } 200 \mathrm{~W}) \\
(\text { Plant } 200 \mathrm{~W})\end{array}$ \\
\hline
\end{tabular}

Borehole Environment Information

\begin{tabular}{|c|c|c|c|}
\hline \begin{tabular}{c} 
Borehole Fluid Depth 232.5 (Feet) from Zero (0.0) Depth Reference of Log \\
\hline $\begin{array}{c}\text { Casing Size } \\
\text { I.D. (inch) }\end{array}$
\end{tabular} & $\begin{array}{c}\text { Casing Thickness } \\
\text { (inch) }\end{array}$ & $\begin{array}{c}\text { Top Depth } \\
\text { (feet) }\end{array}$ & $\begin{array}{c}\text { Base Depth } \\
\text { (feet) }\end{array}$ \\
\hline 8.0 & 0.327 & 0.0 & 249.7 \\
\hline & & & \\
\hline & & & \\
\hline
\end{tabular}

RLS Passive Spectral Gamma Survey Information

\begin{tabular}{|c|c|c|c|c|c|}
\hline \multicolumn{6}{|c|}{$\begin{array}{l}\text { Logging Engineers } \frac{R . V \text {. Cram }}{\text { Log Depth Reference at Zero }(0.0)} \frac{\text { S. E. Kos }}{\text { depth is Ground Leve1 }}\end{array}$} \\
\hline Log Date & $\begin{array}{l}\text { Archive } \\
\text { File Names }\end{array}$ & Log Mode, Speed & $\begin{array}{l}\text { Depth } \\
\text { Top }\end{array}$ & $\begin{array}{c}\text { Interval } \\
\text { Base }\end{array}$ & $\begin{array}{r}\text { (feet) } \\
\text { Incr } \\
\end{array}$ \\
\hline July 13,92 & H2E3324\A204 & MSA $80 \mathrm{sec} \quad$ LT & 0.0 & 75.0 & 0.5 \\
\hline July 14,92 & $\mathrm{H} 2 \mathrm{E} 3324 \backslash \mathrm{A205}$ & MSA $80 \mathrm{sec} L T$ & 73.0 & 191.5 & 0.5 \\
\hline July 15,92 & $\begin{array}{r}H 2 E 3324 \backslash A 206 \\
\text { A206"A" }\end{array}$ & MSA $80 \mathrm{sec}$ LT & $\begin{array}{r}190.0 \\
28.0\end{array}$ & $\begin{array}{r}246.7 \\
53.0\end{array}$ & $\begin{array}{l}0.5 \\
0.5\end{array}$ \\
\hline
\end{tabular}

$1_{\text {MSA: How-Stoo-Acquire LT: Live Time }}$

Calibration and Analysis Information

RLS Calibration Date: Nov 21, 1991

Calibration Report: WHC-SO-EN-TRP-001

Analyst Names: J.P. Kiesler $\quad$ R.K. Price

Analys is Date: August 3, 1992

Analysis Notes: A206" $A^{n}$ is rerun of 28.0 to 53.0 feet with ob shield

Radionuclides identified: $\mathrm{Cs}_{5}-137 \mathrm{C}-\mathrm{CO}_{\mathrm{O}} 60$ 
WHC-SD-EN-TI-257, Rev. 0

\section{RLS Spectral Gamma-Ray Borehole Survey}

Project: 200-BP-1 Remediation Log Date: Jul 13, 92

Borehole: 299-E33-24

Anal. Date: Aug 3, 92

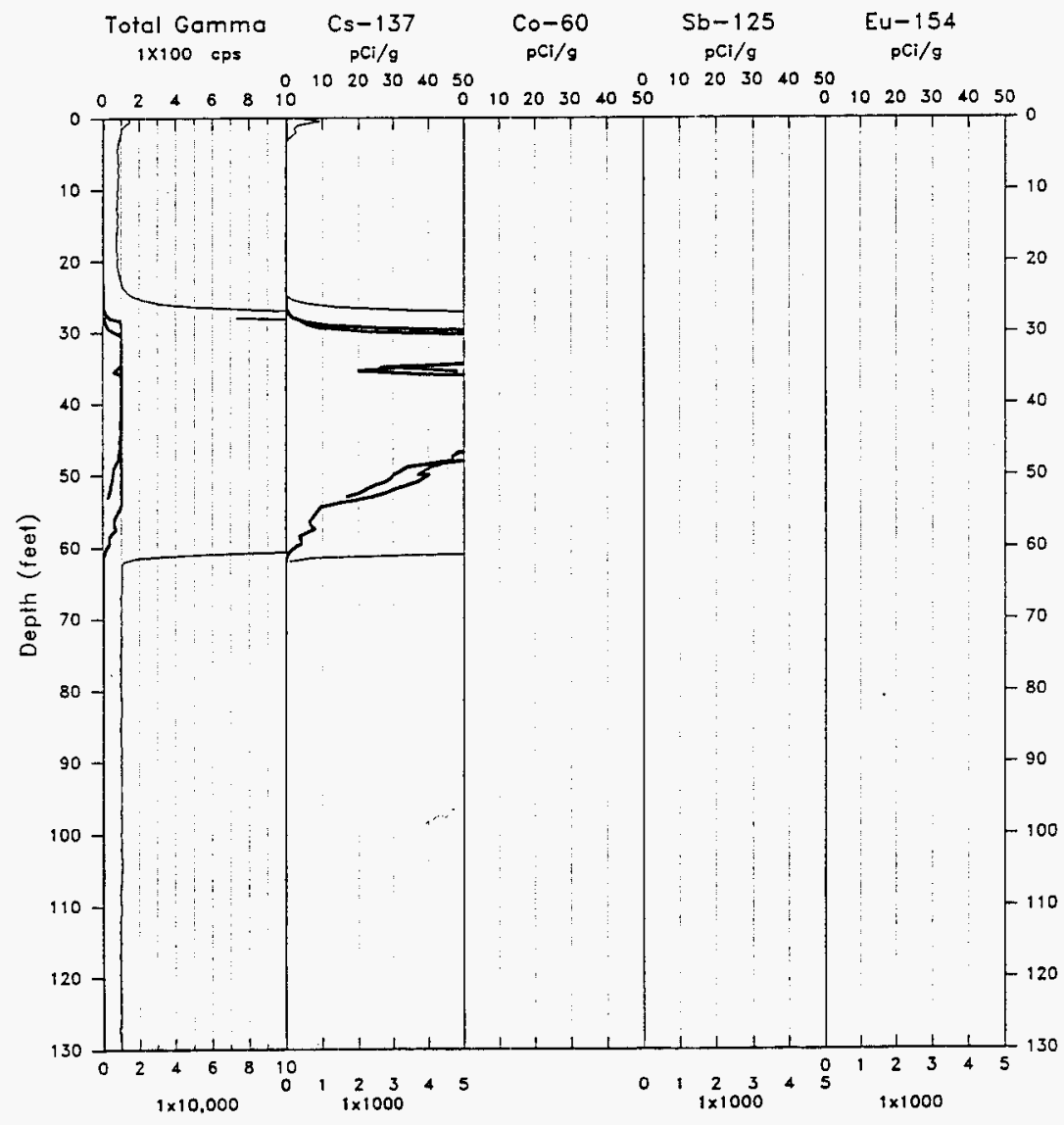

C-' 8 
WHC-SD-EN-TI-257, Rev, 0

\section{RLS Spectral Gamma-Ray Borehole Survey}

Project: 200-BP-1 Remediation Log Date: Jul 13, 92 Borehole: 299-E33-24 Anal. Date: Aug 3, 92

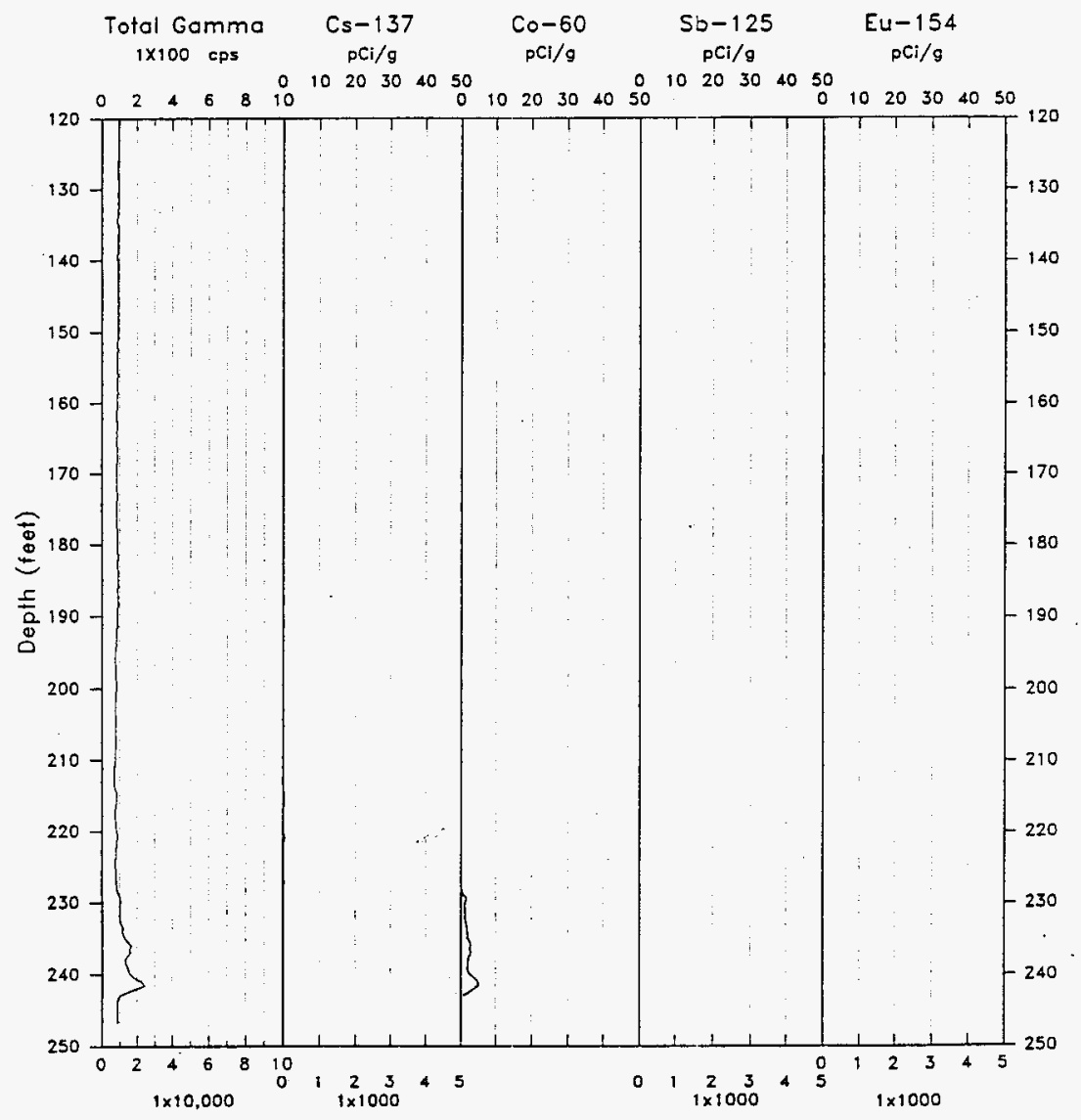

C-9 
WHC-SD-EN-TI-257, Rev. 0

\section{RLS Borehole Survey Report}

$\underline{299-E 33-24 \quad 216-B-57 \mathrm{Crib}}$

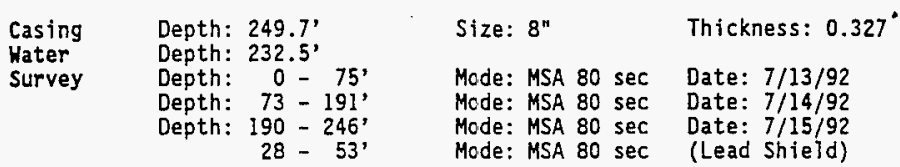

General Notes:

The maximum total gamma count rate reported by the data reduction program "LGCALC" prior to Aug 20, 1992 was 10,000 cps. Total gamma activity from 30 feet to 55 feet exceeded the plotted maximum of 10,000 cps.

Both standard configuration and lead shield logging configuration data surveys are plotted together. The numeric data values of the Total Gamma plot for the two configurations will not produce identical values. No Total Gamma correction for the gamma-ray attenuation from the lead shield has been established.

Computed activity for the man-made radionuclides for both logging. configurations agree within the 2 -sigma uncertainitites.

Man-made radionuclides:

Cesium (Cs-137) was encountered in three zones in the borehole. The depth intervais are: surface to 3 feet, 25 to 63 feet, and 204 to 245 feet. The cesium decay activities exceeded $200 \mathrm{pCi} / \mathrm{g}$ from 28 feet to 60 feet. The decay activity exceeded $5000 \mathrm{pC} i / \mathrm{g}$ from 30 to 35 feet and from 35 to 47 feet.

Cobalt (Co-60) was observed from 228 feet to 243 feet. The maximum decay activity detected was $5 \mathrm{pCi} / \mathrm{g}$ at 241 feet.

No Antimony (Sb-125) was encountered in the borehole. The plot track is present oniy for the uniformity of the displayed data.

No Europium-154 (Eu-154) was encountered in the borehole. The plot track is present only for the uniformity of the displayed data. 
WHC-SD-IEN-TI-257, Rev 0

\title{
APPENDIX D
}

\author{
The RIS System
}

The Radionuclide Logging System (RLS) is a passive, bigh-resolution, gamma-ray energyspectrum, in-borehole logging system. The system utilizes a semi-conducting crystal of high-purity germanium (HPGe); the crystal is cooled during logging with liquid nitrogen, and an electrical potential is imposed across the crystal. Gamma-ray interactions with the crystal produces sharp electrical pulses with energies correlative to the energies of the impinging gamma rays, resulting in excellent gamma-ray energy resolution. This in turn, allows for the direct indentification of the radionuclides from which those gamma rays were emitted. With appropriate calibration, concentrations of the gamma-ray-emitting radionuclides surrounding the borehole can be assayed, as well as identified.

The logging cable equipped on the RLS was specifically designed for the system. It suspends the detector in the well, conducts power to the detector, receives electrical signals from the detector, and provides the conduit for venting the liquid nitrogen component of the detector. Errors in the depth- measuring system of the RLS are mainly related to cable stretch, cable and sheave wheel contact, and electronic encoding components. The recorded depth of the detector is estimated to be accurate to 98.5 percent, with a precision (repeatability) of 99 percent. Comparisons with drilling measurements, other logging equipment, and secondary measuring systems have verified the accuracy. An upgrade in the logging cable and measuring system is being investigated.

There are two configurations in which the logging sonde can be used. One is the as-built state (standard) and the other (alternate) is with an external "shield" (gamma-ray absorbing material) placed around it.

The standard logging configuration optimizes the counting system for detecting low decay activities of radioelements. The RLS has frequently detected man-made radioelement activities of 0.3 $\mathrm{pCi} / \mathrm{g}$ for nuclides emitting gamma rays having energies greater than $500 \mathrm{keV}$ and the number of gamma-rays emitted per decay being at least one for each two decays (greater than 50 percent. The maximum decay activity the RLS has detected is about $10,000 \mathrm{pCi} / \mathrm{g}$ in this standard configuration.

The alternate logging configuration at present employs a lead shield and changes the counting system to maximize the count rate. Configuring the counting system to maximize the count rate compromises its ability to detect radioelements at low decay activities (concentrations). The RLS has frequently detected man-made radioelement activities exceeding $33,000 \mathrm{pCi} / \mathrm{g}$ in this shielded configuration. The alternate logging configuration was not employed for the surveys included in this report because of the low count rates encountered. 
WHC-SD-EN-TI-257, Rev 0

\section{Limitations to the Radioelement Analyses}

The borehole surveys presented in this report have all been analyzed using the calibration data acquired in November 1991. Calculation of the calibration factors used in data reduction depend on the calibration data and on nuclear data (half-lives, branching ratios, number of gamma-rays per decay) for the particular nuclide. All of the nuclear data were taken from Erdtmann and Soyka (1979).

Borehole-environment correction factors have been determined for steel casing and water in the borehole. Correction factors for other borehole configurations have not been investigated. Borehole configurations for which no correction is available include: (1) grout between multiple casing strings, (2) formation seals containing bentonite, sand, or grout behind the casing, and (3) drilling mud remaining inside the borehole during logging. The calculated decay activity for manmade radionuclides will be underestimated for boreholes with these configurations.

Energy-dependent casing corrections have been established for steel casing thicknesses up to 0.40 inches. Corrections for casings of different materials and/or cumulative thicknesses greater than 0.40 inches have not been calculated and therefore cannot be used in the data reduction.

The calibration data were recorded with the detector centered in calibration zones that are uniform in density, water content, and gamma-riay source material. The dimensions of each zone are large enough that the detector always responded as though surrounded by a medium of infinite extent. Therefore, the use of the calibration results to calculate nuclide activity carries the assumption that the nuclides in the logged formation are also distributed in thick uniform layers. Gamma-ray sources are not normally distributed in the earth in thick uniform layers. Source inhomogeneities are reflected to some degree by the fluctuations in the amplitudes of the log traces. A factor called the "vertical spacial resolution" quantifies the correlation between (1) the amplitude of the log fluctuation and the depth interval over which it extends, and (2) the intensity of the corresponding gamma-ray source and the thickness of the zone in which the source is embedded. The vertical spatial resolution of the RLS HPGe logging system is scheduled for investigation.

Radionuclide decay activities are determined from the net area of the gamma-ray peaks. Radioelements, such as strontium-90, which do not emit a gamma ray when they decay will not be identified or quantified by the spectral analysis performed for this report. The decay of strontium-90 results in a high-energy beta particle that can excite surrounding elements to emit photon radiation that can be identified by the HPGe detector. This type of radiation is called "bremsstrahlung" radiation. A method to obtain estimates of the concentrations of strontium-90 is under consideration. 


\begin{tabular}{|c|c|c|c|c|c|}
\hline \multicolumn{6}{|c|}{ DISTRIBIJTION SHEET } \\
\hline \multirow{2}{*}{$\begin{array}{l}\text { To } \\
\text { Distribution }\end{array}$} & \multirow{2}{*}{\multicolumn{3}{|c|}{$\begin{array}{l}\text { From } \\
\text { J.W. Fassett }\end{array}$}} & \multicolumn{2}{|l|}{ Page 1 of 1} \\
\hline & & & & \multicolumn{2}{|c|}{ Date $8 / 29 / 96$} \\
\hline \multirow{2}{*}{\multicolumn{4}{|c|}{$\begin{array}{l}\text { Project Title } \text { Work Order } \\
\text { WHC-SD-EN-TI-257, Spect } \\
216-B-57 \text { Crib Groundwat }\end{array}$}} & \multicolumn{2}{|c|}{ EDT No. 610764} \\
\hline & & & & \multicolumn{2}{|c|}{ ECN No. $\quad$ N/A } \\
\hline \multicolumn{2}{|l|}{ Name } & $\begin{array}{l}\text { Text } \\
\text { With All } \\
\text { Attach. }\end{array}$ & Text Only & $\begin{array}{l}\text { Attach./ } \\
\text { Appendix } \\
\text { Only }\end{array}$ & $\begin{array}{l}\text { EDT/ECN } \\
\text { Only }\end{array}$ \\
\hline $\begin{array}{l}\text { J. W. Fassett } \\
\text { J. I. Feaster } \\
\text { R. K. Price }\end{array}$ & $\begin{array}{l}H 5-06 \\
H 15-06 \\
N 1-55\end{array}$ & $\begin{array}{l}X \\
X \\
X\end{array}$ & & & \\
\hline $\begin{array}{l}\text { Central Files (2) } \\
\text { EDMC (2) }\end{array}$ & $\begin{array}{l}A 3-88 \\
H 15-08\end{array}$ & $\begin{array}{l}X \\
X\end{array}$ & & & \\
\hline
\end{tabular}

